\title{
A Decade Lost and Found: Mexico and Chile in the 1980s
}

\author{
Raphael Bergoeing, Patrick J. Kehoe, \\ Timothy J. Kehoe, and Raimundo Soto
}

Mexico and Chile, like most of the other countries in Latin America, experienced severe economic crises in the early 1980s that led to large drops in output. For these two countries, the paths of recovery from these crises differed markedly. Figure 1 shows that real output per working-age person (15-64) in Mexico was still about 30 percent below trend in 2000, ${ }^{1}$ whereas Chile had returned to trend in about a decade and had grown even faster than trend during the 1990s. ${ }^{2}$ For Mexico, like much of the rest of Latin America, the 1980s were a "lost decade"-whereas for Chile they were a "found decade" in which the economy began to grow spectacularly.

Figure 1. Real GDP per working-age (15-64) person detrended by 2 percent per year

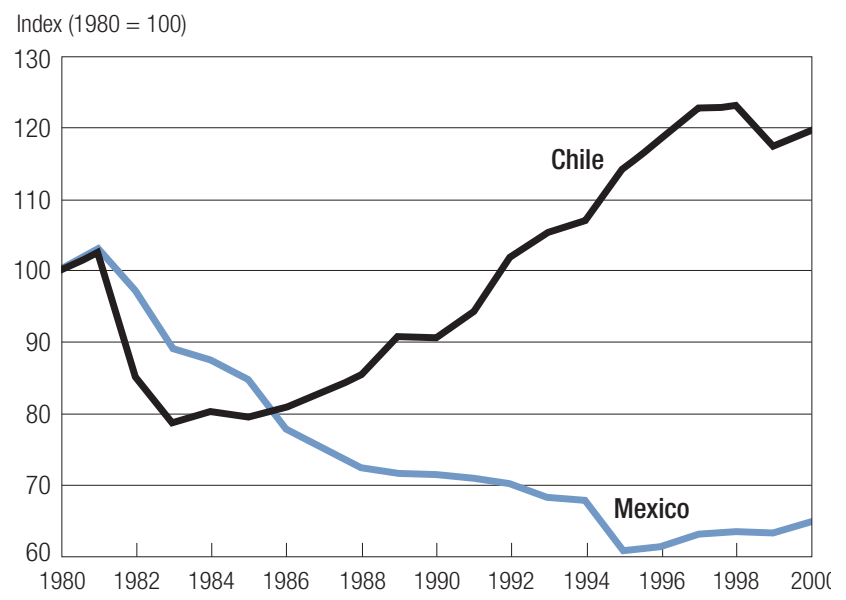


This paper analyzes four possible explanations for the different recovery paths in the two countries. The first explanation is the standard monetarist story: short of inducing a hyperinflation, the more rapidly a country in a severe recession expands its money supply, the faster it will recover. Although this story is not often proposed for the cases of Mexico and Chile, we examine it because it probably is the most common story for both the severity of and the slow recovery from depressions like that of the 1930s in the United States.

The second explanation is Corbo and Fischer's (1994) real-wage story for Chile's rapid recovery. After the crisis, the Chilean government reversed its previous policy of wage indexation and allowed real wages to fall sharply. Corbo and Fischer argue that this policy, together with policies that produced a rapid depreciation of the real exchange rate, fueled an export boom that was the principal cause of the rapid recovery.

The third explanation is Sachs's (1989) debt overhang story for Mexico's slow recovery. Sachs argues that Mexico's large external debt led new investors to fear that most of the returns on any new investment would be taxed to pay off old loans. Hence, new investors were discouraged from investing, and both investment and output remained low.

The fourth explanation is a structural reforms story. Mexico did not undertake a series of structural reforms until the mid-1980s or later, whereas Chile had undertaken these reforms in the 1970s, and that set the stage for the successful performance of the 1980s. We examine reforms in a number of areas: trade policy, fiscal policy, privatization, the banking system, and bankruptcy laws.

For each explanation we ask, Can it explain the different paths of recovery in Mexico and Chile? We find that, although each of the first three explanations has some merit, none of these can account for the different recovery paths. The standard monetarist story implies that Chile should have recovered more quickly than Mexico. The real-wage story implies that exports should have boomed even more in Mexico than in Chile — and they did — but Mexico stagnated while Chile grew. The debt overhang story implies that Chile should have stagnated even more than Mexico.

A comparison of data from Mexico and Chile allows us to rule out only one part of the structural reforms story - trade reforms. The timing of reforms is crucial if they are to drive the differences in economic performance of the two countries. During the decade following the crisis, Mexico's trade grew faster than Chile's, partly because Mexico was engaged in vigorous trade reform, whereas Chile had already carried out substantial trade reform (and, in fact, backtracked from 1983 to 1991). By the mid-1990s, Mexico was just as open as Chile. 
To shed light on the ability of the other reforms to account for the different paths, we turn to a growth accounting exercise. We ask, Were the differences in recoveries due mostly to differences in inputs of capital and labor, or were they due to differences in productivity? We find that most of the differences in the recoveries resulted from different paths of productivity.

Figure 2 depicts detrended total factor productivity (TFP) in Mexico and Chile. As we explain below, these TFP paths would have coincided exactly with the paths for output per working-age person, if factor inputs - measured in terms of the capital-output ratio and hours worked per working-age person-had remained constant. A comparison of Figure 2 with Figure 1 shows that more than two-thirds of the difference in output growth is due to the difference in TFP, leaving about a third to be explained by changes in factor inputs. (See Appendix A for sources of the data used in this paper.)

What causes changes in factor inputs? Some changes in capital accumulation and hours worked are induced by changes in TFP; others can be caused by changes in frictions in factor markets, like taxes and regulations. To distinguish between these two types of changes in factor inputs, we calibrate a growth model of a closed economy in which consumers have perfect foresight over the TFP sequence. Numerical experiments with this model indicate that virtually all of the difference in output between Mexico and Chile was due to the difference in TFP when we include the induced effects on factor inputs. There is no major role left to be played by frictions in factor markets that do not show up in TFP.

\section{Figure 2. Total factor productivity}

detrended by 1.4 percent per year

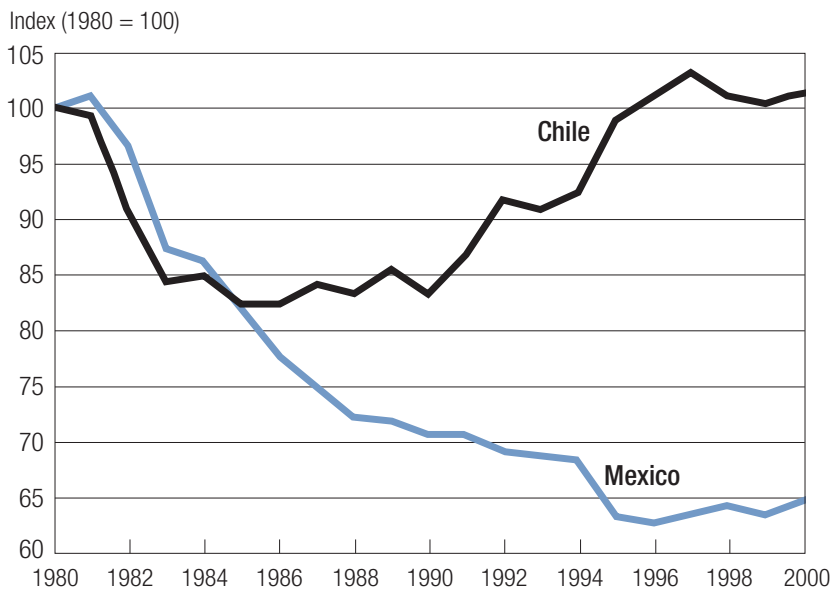


From our growth accounting exercise and numerical experiments, we conclude that the only reforms that are promising as explanations are those that economic theory dictates would show up primarily as differences in TFP, not those that would show up as differences in factor inputs. We use this implication to rule out fiscal reforms. These reforms primarily affect the incentives to accumulate capital and to work, not productivity. Moreover, the timing is not right for the fiscal reforms explanation: both countries had reformed their tax systems by the mid-1980s, so these reforms cannot account for the different paths.

We do find that fiscal reforms are important in explaining some features of the recoveries, just not the differences. In particular, when we use our calibrated model to quantitatively account for the recovery paths for Mexico and Chile, we find that a numerical experiment that incorporates the different paths for TFP but leaves out the fiscal reforms misses badly in both countries. In the same model, however, a numerical experiment that keeps the different paths for productivity and adds an identical fiscal reform in both countries fares much better.

If TFP movements drove both the initial downturns in Mexico and Chile and the difference in their recoveries, what drove the TFP movements? Our hypothesis is that external shocks initiated the TFP drops. These drops were magnified by existing government policies that made the financial sectors in both economies fragile. In Mexico, the policy reaction to the initial shocks increased distortions, resulting in a prolonged decline in TFP. In Chile, however, rapid policy reform led to a recovery of TFP.

In determining which reforms were crucial in driving the difference in the economic performances of the two countries, the matter of timing is crucial: reforms in privatization were probably less important than those in the banking system and bankruptcy laws precisely because Chile had already reaped the benefits of these reforms, whereas Mexico was reaping them during the period in which Mexico was stagnating and Chile was growing. The crucial differences between Mexico and Chile were in banking systems and bankruptcy laws: Chile was willing to pay the costs of reforming its banking system and of letting inefficient firms go bankrupt; Mexico was not. This is not to say that the reforms in Mexican trade policy, fiscal policy, and privatization were not important. The long period of crisis and stagnation that afflicted Mexico from 1982 through 1995 would have been far worse without them.

Two good general references for the economic experience of Mexico are the works of Aspe (1993) and Lustig (1998). Good general references for Chile's experience are the works of Bosworth, Dornbusch, and Labán (1994); Corbo (1985); and Edwards and Edwards (1991). Edwards (1998) provides an interesting comparison of the 1994-95 crisis in Mexico with the 1981-83 crisis in Chile. 


\section{Different Reactions to Similar Initial Conditions}

In the early 1980s, Mexico and Chile faced fairly similar conditions, at least on the macroeconomic level. Both countries had sizable foreign debts, appreciating real exchange rates, large current account deficits, and weaknesses in the banking system. Both countries were also hit by similar external shocks. These shocks consisted of a jump in world interest rates, plummeting prices of their primary exports, and a cutoff of foreign lending.

Some simple data provide a feel for the initial conditions. Like many developing countries, Mexico and Chile took advantage of low world interest rates in the late 1970s to build up large levels of foreign debt. By 1982, total external debt in Mexico, which had grown by 140 percent in U.S. dollars since 1978, was 53 percent of gross domestic product (GDP). By 1982 in Chile, total external debt had grown by 134 percent in U.S. dollars since 1978 and was 71 percent of GDP. The real exchange rate against the U.S. dollar - and the United States was by far both Mexico and Chile's largest trading partner-had appreciated by 27 percent in Mexico and by 26 percent in Chile between 1978 and 1981. By 1981 the current account deficit in Mexico was 5.8 percent, whereas in Chile it was 14.5 percent of GDP. By the end of 1982, foreigners stopped financing new capital inflows, and the current account deficits disappeared. The banking systems in Mexico and Chile were so vulnerable to the shocks that buffeted their economies that, in each country, the government found it necessary to take over private banks: in Mexico the government nationalized all banks, and in Chile the government took over distressed banks and nonbank financial institutions (financieras) that held more than 55 percent of the assets in the financial sector.

The following data provide a feel for the magnitude of the external shocks. Loans to Mexico and Chile were offered at a spread over the London Inter Bank Offered Rate (LIBOR). Between 1978 and 1981, in response to contractionary U.S. monetary policy, the three-month U.S. dollar LIBOR jumped from 8.8 percent to 16.8 percent per year. In the early 1980 s, Mexico was heavily dependent on its exports of crude petroleum, which accounted for 52 percent of total exports in 1980. Chile was similarly heavily dependent on its exports of copper, which accounted for 48 percent of its total exports in 1980. Figure 3 plots the prices of crude petroleum and copper relative to the U.S. producer price index (PPI). The relative price of crude petroleum fell 21 percent between 1980 and 1982, while that of copper fell 39 percent. By the end of 1982, following Mexico's default, essentially no new private foreign loans were granted to Mexico or Chile until the end of the decade: although Mexico's total external debt increased by 9 percent between 1982 and 1989 and Chile's total external debt increased by 4 percent, almost all of 
Figure 3. Commodity prices deflated by U.S. PPI

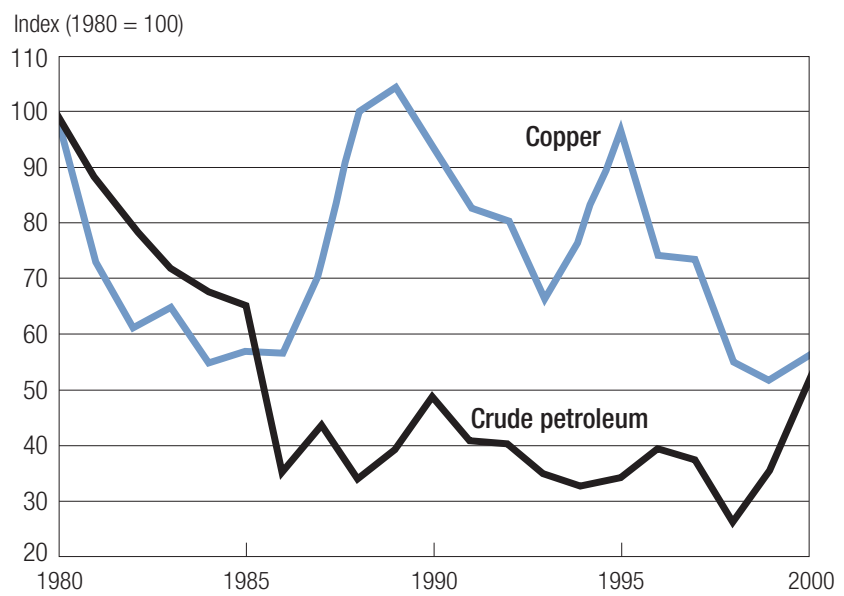

the increases can be accounted for by loans from the International Monetary Fund and, in the case of Mexico, accumulation of unpaid interest.

\section{Different Stories for Different Recoveries}

Despite the similarities in their initial conditions, Mexico and Chile experienced very different recoveries from their crises. In this section, we consider four potential explanations for these different recoveries. Comparing the case of Mexico with that of Chile allows us to rule out three of these explanations: although a story may have some merit when applied to one of the countries in isolation, we rule it out if it is incapable of explaining the differences between the experiences of the two countries.

\section{Standard Monetarist Story}

Crudely stated, the standard monetarist story is as follows. Short of inducing a hyperinflation, the more rapidly a country in a severe recession expands its money supply, the faster it recovers. We include this story not because it has been proposed as a serious explanation of these episodes, but rather because it is probably the most common story for recovery from crisis. Even though we have oversimplified the story, the basic theme can be found in Friedman and Schwartz's (1963) analysis of the Great Depression in the United States and is pervasive in the literature.

Figure 4 presents data on rates of growth of the money supply and inflation rates for both Mexico and Chile. If we focus on 1983-95, the crucial period in which Mexico was mired in crisis while Chile was growing, we see 
Figure 4. Money growth and CPI inflation
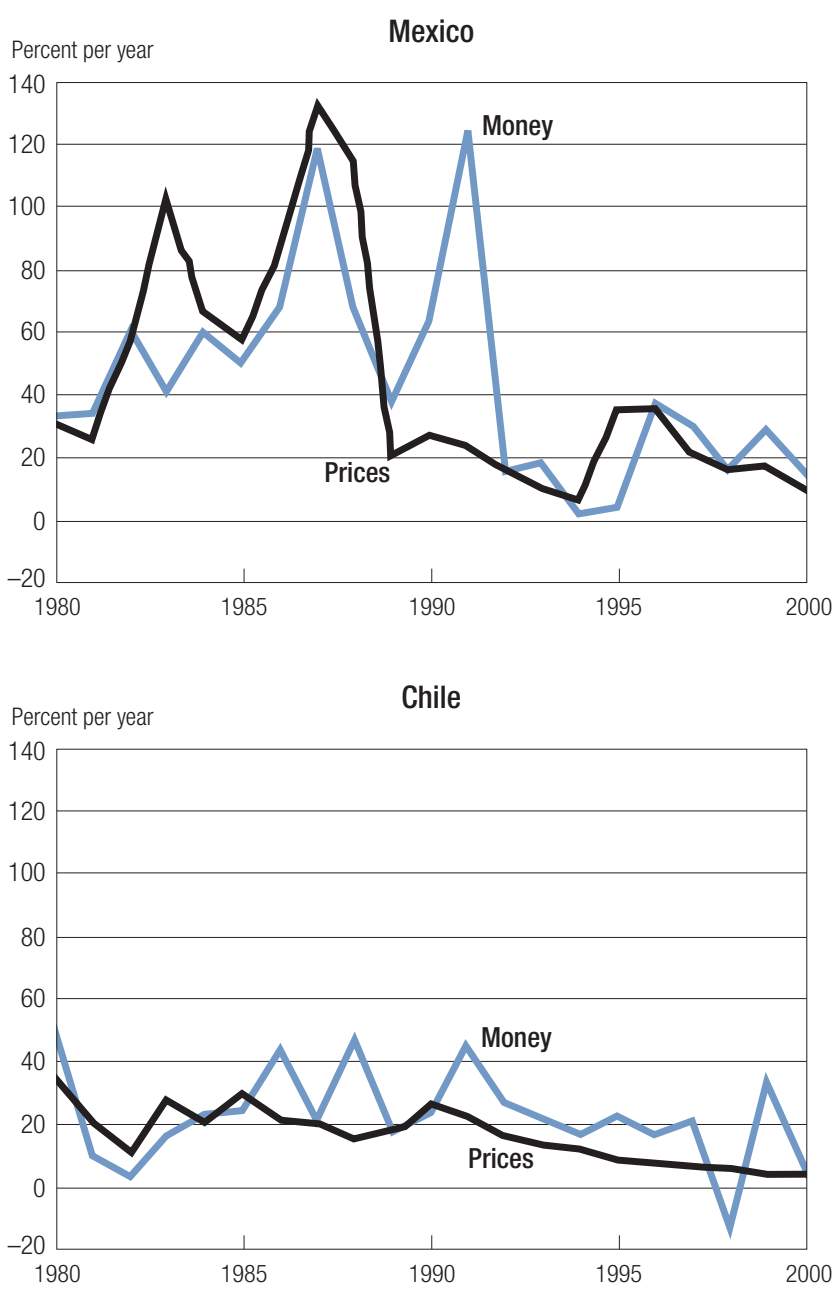

that the annual growth rate of the money supply was substantially higher in Mexico than in Chile. This higher growth of money was associated with a faster growth of prices in Mexico than in Chile. It does not show up, however, in a faster growth of output for Mexico in Figure 1. Indeed, output per working-age person contracted in Mexico while it grew in Chile. Of course, even the most avid proponents of the monetarist story do not claim that monetary forces can account for a decade of growth. Nevertheless, it is interesting that these forces seem incapable of explaining even a single year or two of 
the output path following the crisis: for every year in the period 1983-88, Mexico had a higher growth rate of money but a lower growth rate of output per working-age person relative to Chile.

While the monetarist story seems unable to account for the different paths of recovery, part of the downturn may well be associated with monetary factors. The jump in world interest rates that adversely affected Mexico and Chile was clearly associated with a monetary contraction in the United States. Moreover, in a failed effort to defend its nominal exchange rate, Chile contracted its money supply during the first three quarters of 1982, and this policy may have deepened and prolonged its crisis. Of course, this argument begs the question of why Chile recovered so rapidly while Mexico, which had no contraction, did not.

Although we have treated the monetarist story in a superficial manner, at first blush it does not seem to be a promising route to follow. More generally, in most Latin American countries, high inflation is often associated with large drops in output, not with substantial recoveries. It may be that this pattern for Latin America is quite different from the patterns in the United States and Europe in which large drops in output are associated with deflations, not inflations. If so, this is an area that warrants further study.

\section{Real-Wage Story}

In an influential article, Corbo and Fischer (1994) argue that one of the principal causes of Chile's crisis in the early 1980s was the government's policy of mandating that wages be adjusted at least one-for-one with past inflation, while at the same time fixing the nominal exchange rate for the four years before the crisis. Given the high inflation the country had already experienced, these policies led to a continuation of past inflation, an appreciation of the real exchange rate, and a sharp increase in real wages. After the crisis, the government reversed its position. It undid its wage indexation policies and allowed the real exchange rate to depreciate.

Figure 5 shows that real wages in manufacturing in Chile declined by 15 percent in the two years after 1982. Furthermore, as shown in Figure 6, between 1982 and 1987, Chile's real exchange rate against the U.S. dollar depreciated by 124 percent. This decline in wages, together with the depreciation of the real exchange rate, according to Corbo and Fischer (1994), generated an export boom (as shown in Figure 7) that was the principal cause of Chile's rapid recovery.

The story of declining real wages and a depreciating real exchange rate generating an export boom that spurred the recovery sounds convincing for Chile. But can it explain the differences in the economic performances of Mexico and Chile? Probably not. The fall in real wages was substantially 
Mexico and Chile in the 1980s

Figure 5. Index of real wages in manufacturing

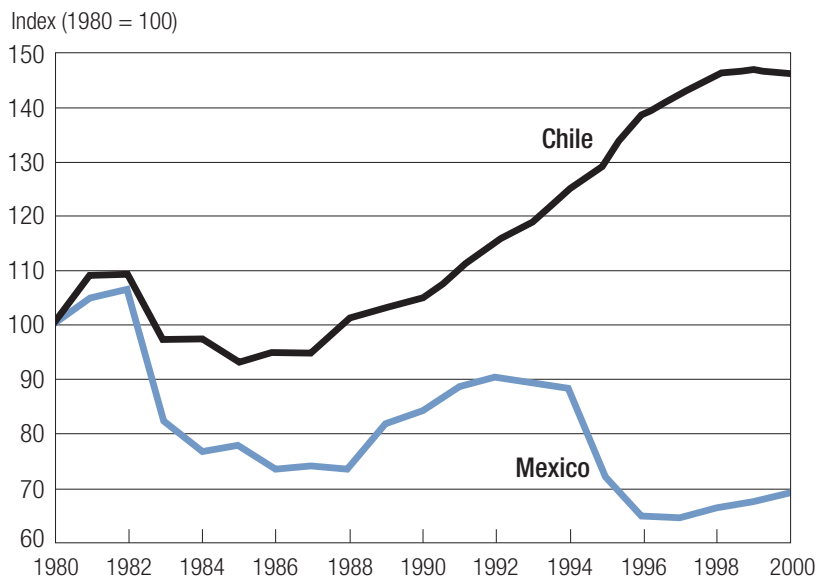

Figure 6. Real exchange rate against the U.S. dollar

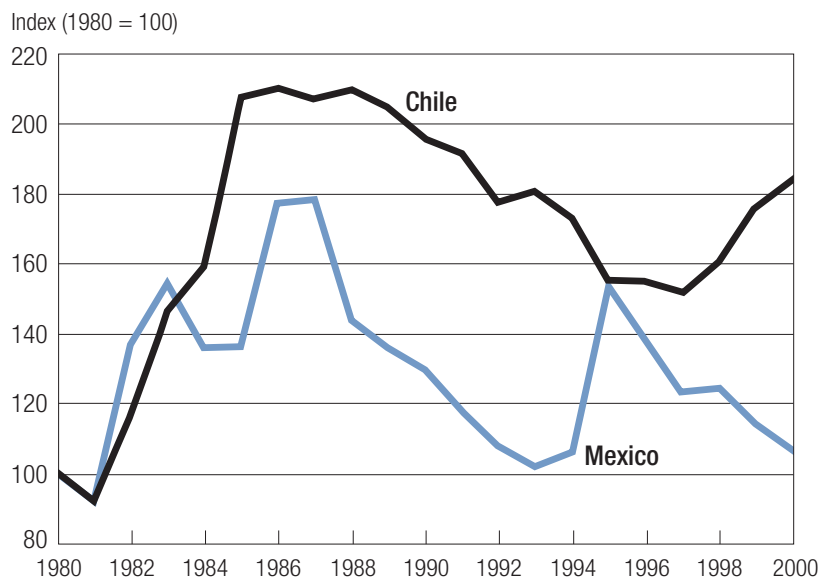

greater in Mexico than in Chile: in the two years following the crisis, real wages fell by almost 30 percent in Mexico, compared with 15 percent in Chile. Furthermore, between 1981 and 1987, the Mexican peso depreciated by 95 percent (from 92 to 179) against the U.S. dollar, compared with 124 percent in Chile (from 92 to 207). As Figure 7 shows, exports boomed in Mexico as well as in Chile as a percentage of GDP.

The data in Figure 7, which express exports as a percentage of GDP, can be misleading as indicators of the movements in value of exports when there 
Figure 7. International trade as a percentage of GDP

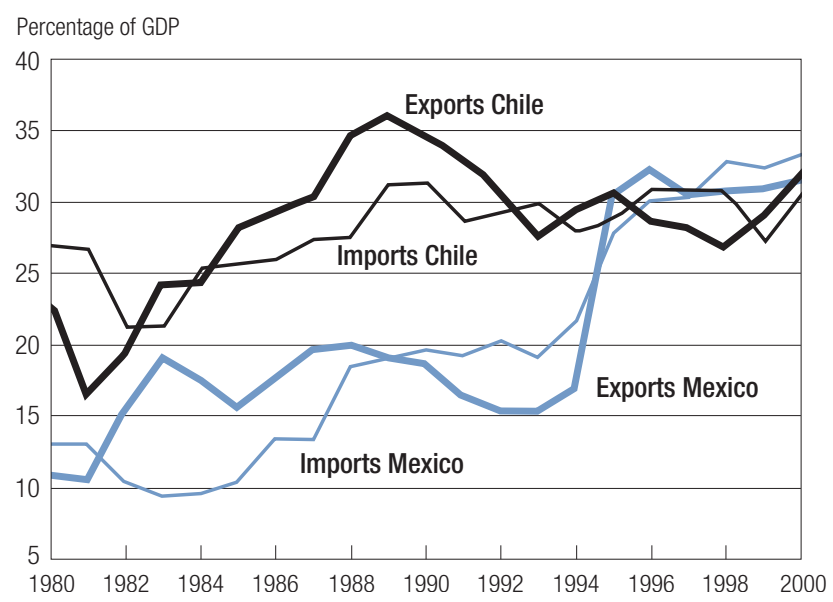

Figure 8. Export value in U.S. dollars deflated by U.S. PPI

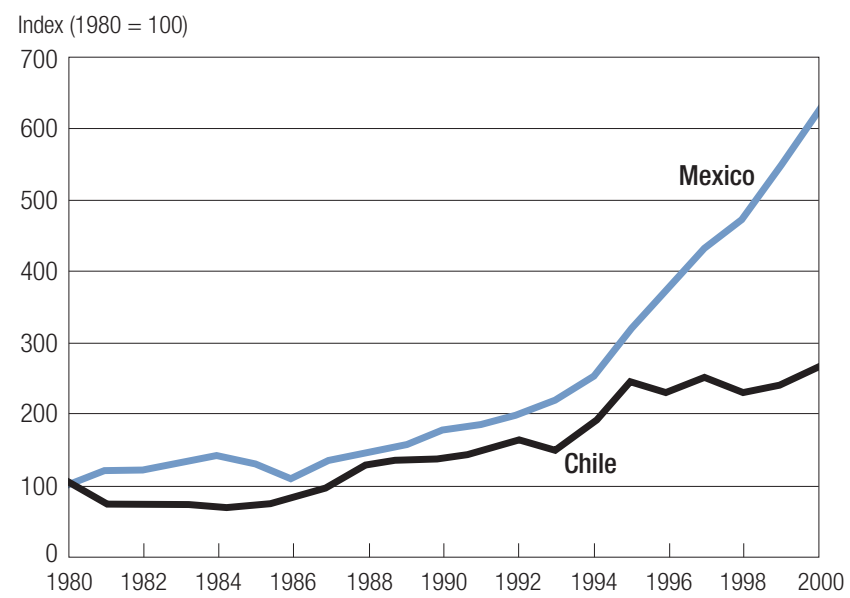

are substantial fluctuations in GDP and in the real exchange rate. Looking at the value of exports in U.S. dollars deflated by the U.S. PPI in Figure 8, we see that the value of Mexico's exports rose after 1981, falling below its 1981 level only briefly in 1986, whereas the value of Chile's exports actually fell after 1981. Much of the movement in the dollar value of Mexico's and Chile's exports should come as no surprise, given the data on commodity prices in Figure 3. What is surprising is that, even though the price of copper 
recovered in the late 1980s and early 1990s and the price of crude petroleum did not, the dollar value of Mexico's exports grew faster than Chile's did during this period. By 2000, Mexico was exporting 427 percent more than it had in 1981, measured in terms of deflated U.S. dollars, while Chile was only exporting 250 percent more. Moreover, returning to Figure 7, we see that by 2000, Mexico's ratio of trade to GDP exceeded Chile's - even though Mexico's economy was seven times larger, and smaller countries typically have much higher ratios of trade to GDP.

Declining real wages and a depreciating real exchange rate generated an export boom in Mexico but had a lesser effect in Chile. Yet, after 1983, Mexico's economy stagnated while Chile's rapidly recovered. Consequently, we need to look elsewhere for an explanation of the differences in the recoveries.

\section{Debt Overhang Story}

A hypothesis often associated with Sachs (1989) for Mexico's slow recovery is the debt overhang story. The idea is that Mexico's large external debt led to fears by potential new investors that most of the returns on any new investment would eventually be used to pay down old loans. Potential new investors viewed the outstanding debt as leading to future (implicit or explicit) taxes on the returns to their new investments. Hence, these investors were discouraged from making new investments, and private incentives were distorted toward consuming rather than investing. The larger the outstanding debt, the higher the implicit tax on new investment, and the lower the actual investment.

To analyze this story, we plot the ratio of external debt to output in Mexico and Chile in Figure 9, and we plot the investment rate in these two countries in Figure 10. It is clear that, both during and after the crisis, Mexico had an increasing ratio of debt to output and that, during the same period, Mexico's investment-output ratio fell below its pre-crisis level. So, at least for Mexico, the pattern is not inconsistent with Sachs's story.

Can Sachs's story explain the difference between Mexico's slow recovery and Chile's fast one? As Figure 9 makes clear, both during and after the crisis, Mexico had a much lower debt-output ratio than Chile. Furthermore, in Figure 10, we see that Mexico's investment rate fell less abruptly than Chile's, and it was not until 1989 that Chile caught up and passed Mexico. Looking at macroeconomic aggregates like investment rates, we do not see how debt overhang can explain the different recoveries of Mexico and Chile.

Before we leave the debt overhang story, two comments are in order. First, in some versions of the debt overhang story, it is the quantity of public debt that impedes new investment. At the onset of the crisis, Mexico's portion of public debt was larger than Chile's: in 1981, 80.8 percent of Mexico's debt 
Figure 9. Total external debt as a percentage of GDP

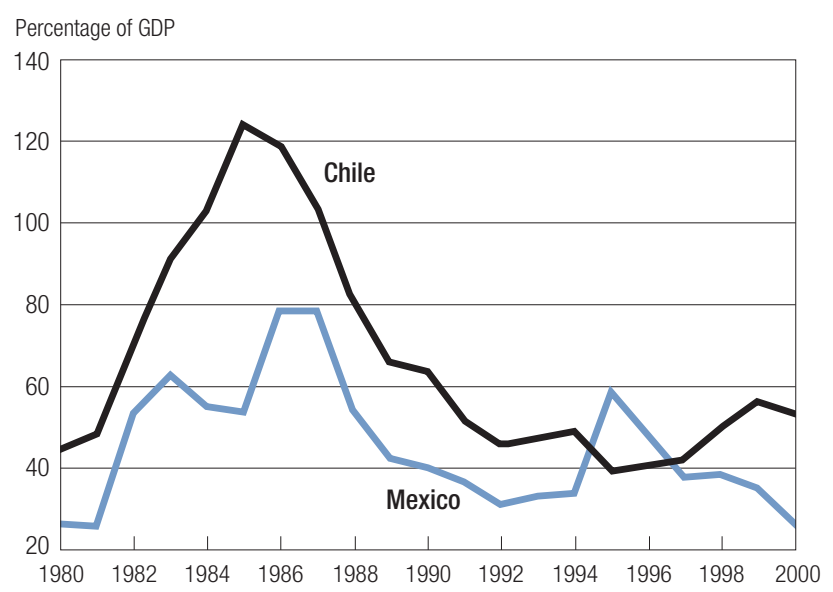

Figure 10. Investment as a percentage of GDP

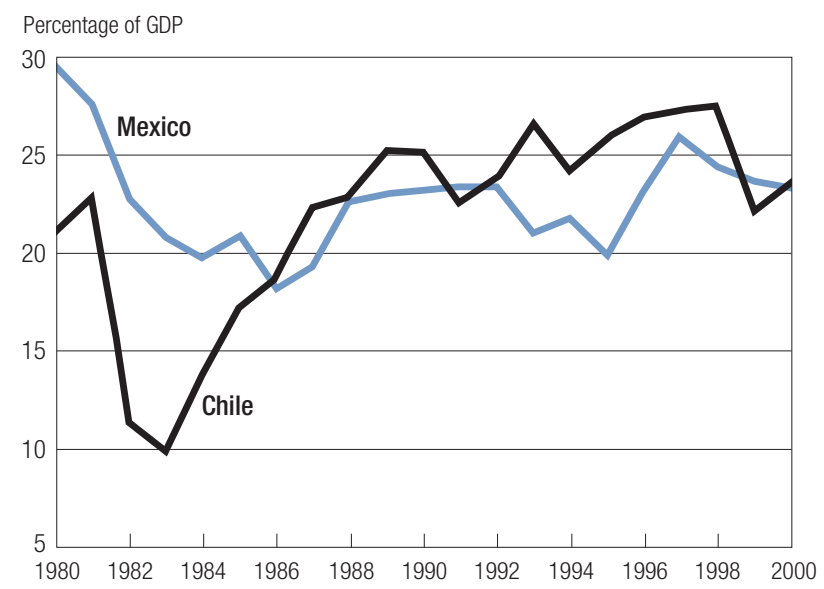

was public or publicly guaranteed, as compared with 35.6 percent in Chile. Following the government bailout of Chile's banking system, however, the portion of debt in Chile that was public or publicly guaranteed shot up, reaching 86.3 percent in 1987, compared to 85.6 percent in Mexico. If the crucial factor in the debt overhang story is the level of public debt rather than that of total debt, Chile had more public debt overhang during the crucial period when it was recovering and Mexico was not.

Second, comparing Figure 9 with Figure 6, we see that most of the fluctua- 
tions of both countries' ratios of debt to output were due to depreciation of the domestic currency. This depreciation increased the relative value of debt, which was mostly denominated in U.S. dollars. This suggests that Sachs's debt overhang story for Mexico's stagnation, which says that depreciation is bad because it drives up the relative value of foreign debt, conflicts with Corbo and Fischer's real-wage story for Chile's recovery, which says that depreciation is good because it drives up exports. Neither story is capable of explaining the differences between the economic performances of Mexico and Chile.

\section{Structural Reforms Story}

A promising explanation of the different recovery patterns is that Mexico did not undertake structural reforms until the mid-1980s or later, whereas Chile had already undertaken structural reforms in the 1970s, and these reforms set the stage for successful performance of the economy in the 1980s. These reforms covered trade policy, fiscal policy, privatization, the banking system, and bankruptcy laws. Could the different timing of the reforms have determined the different recovery patterns? Here we argue that neither trade policy reforms nor fiscal reforms can explain the differences. Privatization, banking, and bankruptcy reforms, however, may well be able to offer an explanation.

Consider first the differences in trade policy. (See, for example, De la Cuadra and Hachette 1991 and Kehoe 1995.) We argue that Mexico engaged in far more trade reform during the period 1983-95 than did Chile. By 1979 Chile had eliminated all quantitative restrictions on imports and imposed a uniform tariff of 10 percent. In Chile, the uniform tariff was increased to 20 percent in 1983, to 35 percent in 1984, and then was gradually lowered until it fell below its original level in 1991. In Mexico, there was massive protection in 1985: in addition to tariffs, import licenses protected 100 percent of domestic production, and there were numerous other nontariff barriers and a system of dual exchange rates that gave preferred treatment to industries favored by the government. Starting in the mid-1980s, however, Mexico embarked on a trade liberalization policy that culminated in the implementation of the North American Free Trade Agreement in 1994. Trade liberalization, like real exchange rate depreciation, generated exports in both Mexico and Chile, but it is hard to see how differences in the timing determined the different recoveries. As we have seen in Figures 7 and 8, trade grew more in Mexico than in Chile during the crucial period 1983-95, partly because Mexico was more closed than Chile to start with.

Next consider differences in fiscal policy. We argue that both countries engaged in significant tax reforms during the 1980s. In Mexico, there were 


\section{Figure 11. Government surplus as a percentage of GDP}

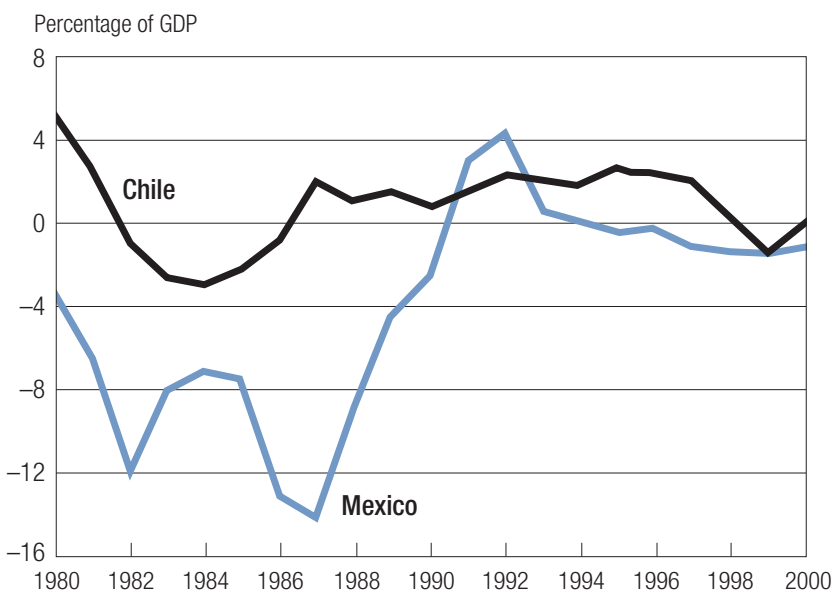

major tax reforms in 1980 and in 1985. Corporate tax policy in Mexico was reformed in 1987 and 1989 to lower distortions on investment. In Chile, there was a major tax reform in 1975, a major social security reform in 1980, and another major tax reform in 1984. As Figure 11 indicates, throughout much of the 1980s, Mexico ran a deficit on the order of 10 percent of GDP, whereas Chile ran either a government surplus or a small deficit. Fiscal reforms undoubtedly played important roles in both Mexico and Chile in inducing higher rates of capital accumulation and hours worked. Hsieh and Parker (2001), for example, stress the importance of tax reforms in spurring investment in Chile. In the next section, we use growth accounting and numerical experiments with a growth model to argue that these reforms had roughly similar impacts on both economies - leaving the difference in their performances still unexplained.

Now consider differences in privatization. (See, for, example, Glade 1996 and Hachette and Luders 1993.) We argue that, although both countries underwent substantial privatization, it is unclear which privatization program had the most important impact in the early 1990s when Mexico was stagnating and Chile was growing. Following the 1982 crisis in Mexico, the government nationalized the banking system and, moreover, effectively appropriated the banks' holdings of private companies. Economists like Lustig (1998) estimate that, directly or indirectly, the government controlled from 60 to 80 percent of GDP. In 1984, Mexico began to reprivatize what it had nationalized, but only after 1989 was the reprivatization substantial. The nationalized banks were only privatized after 1990. In contrast, in Chile, a large fraction of the economy 
had been under direct or indirect government control since the end of the Allende administration in 1973. From 1974 to 1979, the Chilean government had reprivatized much of the economy. The different paces of privatization in the two countries had effects both on the incentives to accumulate capital and on the efficiency with which that capital was allocated.

It is worth pointing out, however, that it is easy to exaggerate the importance of privatization in Mexico relative to that in Chile: crude petroleum exports in Mexico, which are controlled by the government's Petróleos Mexicanos (PEMEX), accounted for 9.8 percent of Mexico's exports in 2000. Although the number of state enterprises in Chile was reduced from 596 in 1973 to 48 in 1983, the portion of GDP generated by state enterprises only fell from 39 percent to 24 percent. Chile's national copper company, Corporación Nacional del Cobre (CODELCO), was still run by the government in 2000 , and its exports of copper accounted for 13.8 percent of Chile's exports. Significantly, however, the government in Mexico has not allowed private competition in petroleum extraction, whereas the government in Chile has allowed private competition in copper extraction.

We now turn our attention to the banking system. (See, for example, Barandiarán and Hernández 1999 and Gruben and Welch 1996.) We argue that it is in this area, together with that of bankruptcy procedures, that lack of reforms left Mexico to stagnate while timely reforms in Chile spurred its recovery. One way that differences in the workings of the banking systems manifested themselves was in the amount of private lending in the two economies. Figure 12 graphs private credit (which consists of all loans to the private sector and to nonfinancial government enterprises) as a percentage of output. Clearly, substantially less private lending was taking in place in Mexico relative to that in Chile. In Mexico, banks were few, highly regulated, and subject to very high reserve requirements. The government set very low deposit rates in order to give low-interest-rate loans to preferred industries. Overall, the banking system in Mexico was used by the government as a way to channel funds to preferred borrowers at low interest rates.

In contrast, in 1973 Chile had eighteen national banks and one foreign bank. After a series of financial reforms that included deregulation, low reserve requirements, and opening to foreign competition, the number of financial institutions increased by 1980 to twenty-six national banks, nineteen foreign banks, and fifteen financieras - the latter being nonbank financial institutions that were subject to less stringent regulations than banks. The explosion of financial institutions that were not highly regulated and that paid market-determined interest rates led to an explosion in private credit.

These differences in banking systems led to huge differences in the allocation of credit in the two economies after the crisis. In Mexico, credit 
Figure 12. Private credit as a percentage of GDP

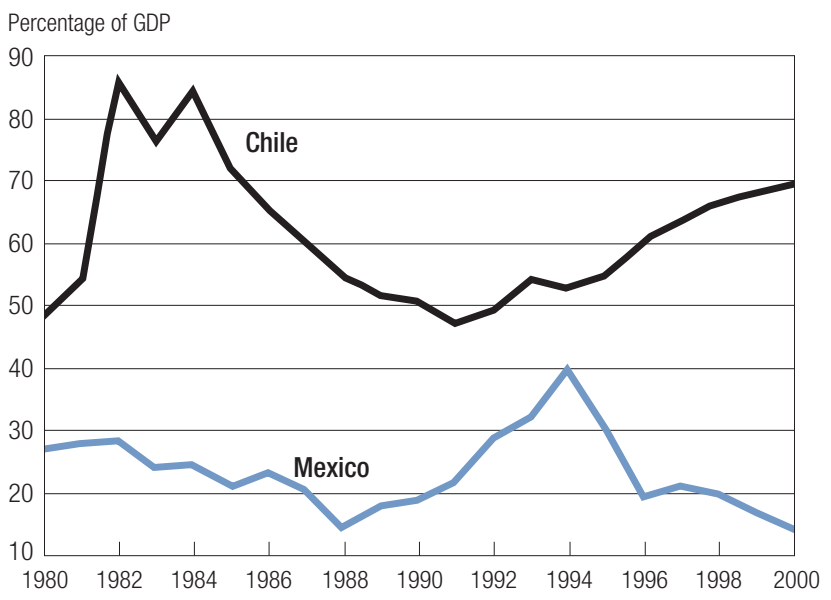

allocation was determined by the government; in Chile, it was determined mostly by the market. Although banks and financial institutions collapsed and were taken over by the government in both countries, the authorities reacted in very different ways when rescuing the financial sector and restoring credit flows.

In Mexico, banks were nationalized and credit was allocated discretionarily at below-market rates. Figure 12 shows that credit to the private sector fell in Mexico after 1982 and continued to be very low for most of the decade. In fact, despite the massive bailout during the 1994-95 crisis, Mexico's banking system still failed to provide credit to the private sector at levels comparable to that in Chile even in the late 1990s. In contrast, in Chile credit to the private sector expanded during 1982-85 and steadily declined as a fraction of GDP during the rest of the decade mostly because of GDP growth. In retrospect, it appears that the immediate cost of the bank bailout paid for by Chile during the crisis was more than compensated by later gains.

In Chile, Chilean authorities liquidated insolvent banks and financieras, quickly reprivatized solvent banks that had been taken over because of liquidity problems, and set up a new regulatory scheme to avoid mismanagement. Banks were able to channel credit to firms at market rates - which were very high immediately following the crisis. The banking reforms in Chile were costly: Sanhueza (2001) estimates that during 1982-86, the costs amounted to 35 percent of one year's GDP.

Finally, consider differences in the timing of the reform of bankruptcy procedures. Mexico had an obsolete and unwieldy bankruptcy law from 
1943 in place until 2000. The 2000 bankruptcy law includes features similar to Chile's 1982 law, particularly the establishment of bankruptcy specialists (especialistas de concursos mercantiles), who are intended to play much the same role as poorly paid public officials (sindicos) in Chile. Our interpretation is that Chile paid the short-term costs of letting many firms fail, and this led to a sharp, but short, fall in output followed by a strong recovery. Mexico, in contrast, attempted to muddle through the crisis. It had a less severe initial downturn, but a much weaker recovery.

In Chile, the 1929 bankruptcy law did not provide for an efficient and timely administration of bankruptcies because it relied on sindicos and highly bureaucratic procedures. Until the late 1970s, bankruptcy proceedings languished for years in courts. Following an administrative reform of the bankruptcy management service in 1978, the 1982 bankruptcy reform law clearly defined the rights of each creditor and replaced public sindicos with private sindicos. The law was passed at the onset of the crisis, and the government allowed firms to go bankrupt, avoiding the use of subsidies to keep them afloat, under the conviction that protection would unnecessarily lengthen the adjustment period.

It was this reform to bankruptcy procedures, in retrospect, that was crucial in making the initial phase of the crisis less severe in Mexico than in Chile. Figure 13 shows that bankruptcies increased fivefold between 1980 and 1982 in Chile, but quickly returned to average levels. ${ }^{3}$

Like privatization and the reforms in banking, the reform of bankruptcy procedures in Chile had effects both on the incentives to accumulate capital

\section{Figure 13. Business bankruptcies in Chile}

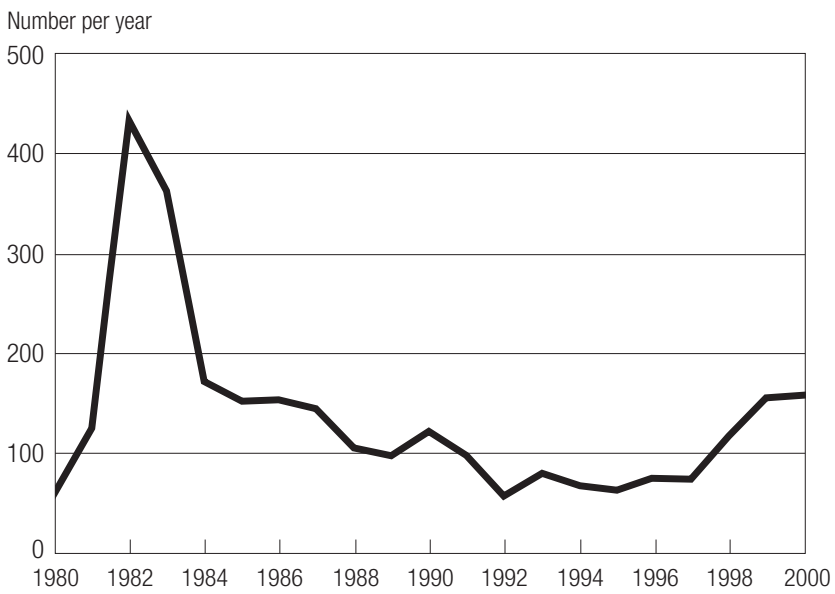


and on the efficiency with which that capital was allocated. We argue in all three of these cases that it was effects on efficiency that were crucial for explaining the differences between Mexico and Chile after the crisis. Some support for that view is given by the data in Figure 10, which show that the investment rate in Mexico was not much below that in Chile. Our growth accounting analysis in the next section bolsters this view, namely, that most of the differences in the recovery paths stem from differences in productivity and not from differences in factor inputs. Hence, for these types of reforms to account for the different recovery paths, they must have two features. First, they must show up primarily in productivity. Second, given the timings of reforms discussed above, they must have dynamic effects on productivity that show up gradually over time.

\section{Growth Accounting and the Growth Model}

To see whether the different timing of reforms can explain the different economic performances of Mexico and Chile, we use growth accounting to answer two questions: What portion of the different performances of Mexico and Chile can be accounted for by differences in inputs of capital and labor? What portion can be accounted for by differences in the efficiency with which these factors were used?

\section{Growth Accounting}

In this paper, we employ the aggregate Cobb-Douglas production function

$$
Y_{t}=A_{t} K_{t}^{\alpha} L_{t}^{1-\alpha},
$$

where $Y_{t}$ is output, $A_{t}$ is total factor productivity (TFP), $K_{t}$ is capital, $1>\alpha>0$ is the capital share, and $L_{t}$ is labor,

$$
A_{t}=Y_{t} /\left(K_{t}^{\alpha} L_{t}^{1-\alpha}\right)
$$

To calculate $A_{t}$, given series for $Y_{t}$ and $L_{t}$, we need to choose a value for $\alpha$ and to generate series for $K_{t}$. National income accounts indicate that the share of labor compensation in GDP valued at factor prices (GDP at market prices minus indirect taxes) in both Mexico and Chile is small relative to, say, that in the United States. In 1980, for example, according to the United Nations (1986), this share-which corresponds to $1-\alpha$ in our production function - was 0.42 in Mexico and 0.53 in Chile. Nevertheless, we choose a higher value of the labor share for our growth accounting and numerical experiments, 0.70 - corresponding to $\alpha=0.30$ - for two reasons. First, measured labor compensation fails to account for the income of most self- 
employed and family workers, who make up a large fraction of the labor force in countries like Mexico and Chile. Gollin (2001) shows that, for countries where there are sufficient data to adjust for this mismeasurement, the resulting labor shares tend to be close to the value in the United States, 0.70. In addition, García-Verdú (2005) studies Mexican household survey data and concludes that the aggregate Mexican labor share is close to the U.S. value. Second, a high capital share implies implausibly high rates of return on capital in our numerical experiments. (We provide alternative growth accounting and numerical experiments for a production function in which $\alpha=0.60$ in Appendix B; the qualitative nature of our conclusions does not change.)

To calculate a capital stock series, we cumulate investment, $I_{t}$, using

$$
K_{t+1}=(1-\delta) K_{t}+I_{t}
$$

for some chosen depreciation rate $\delta$ and an initial condition on capital. We use a depreciation rate $\delta=0.05$ for both countries, and for the initial condition on capital, we assume the capital-output ratio was the same in 1950 in Mexico as its average for 1951-80 and the same in 1960 in Chile as its average for 1961-80. ${ }^{4}$ As a check, we note that with these choices the share of capital consumption in GDP, which in the model is measured by $\delta K_{t} / Y_{t}$, is equal to the number reported by the United Nations (1986) for Mexico in 1980. To reproduce the corresponding number for Chile in 1980, we would need a higher depreciation rate, $\delta=0.08$. We choose to use $\delta=0.05$ for two reasons. First, we want to use the same production technology in our growth accounting and numerical experiments for Mexico as for Chile. Second, a higher value of $\delta$ for Chile yields implausibly low values of the capital-output ratio there. (We provide alternative growth accounting and numerical experiments for a production technology in which $\delta=0.08$ in Appendix B; the qualitative nature of our conclusions does not change.)

Given our choice of $\alpha$ and generated series for $K_{t}$, we can calculate TFP series. Recall that Figure 2 plots the TFP series for Mexico and Chile detrended by 1.4 percent per year. We detrend at this rate because in a balanced-growth path, where output and capital per worker grow by 2 percent per year, TFP would have to grow by 1.4 percent per year, $1.02^{1-0.3}=1.0140$. What is striking about Figure 2 is how closely the TFP data match those for GDP per working-age person in Figure 1. (In fact, the correlation between detrended $A_{t}$ and detrended $Y_{t} / N_{t}$ is 0.99 for Mexico and 0.92 for Chile. Here $N_{t}$ is the number of working-age persons.) This similarity suggests that changes in inputs were not what was responsible for the crises and recoveries in Mexico and Chile, but rather the efficiency with which these factors were used. 
Taking natural logarithms of the production function, we follow the work of Hayashi and Prescott (2002) in rearranging terms to obtain

$$
\log \left(\frac{Y_{t}}{N_{t}}\right)=\frac{1}{1-\alpha} \log A_{t}+\frac{\alpha}{1-\alpha} \log \left(\frac{K_{t}}{Y_{t}}\right)+\log \left(\frac{L_{t}}{N_{t}}\right) .
$$

We use this expression to decompose the change in real GDP per capita over the period $t$ to $t+s$ as

$$
\begin{aligned}
& {\left[\log \left(\frac{y_{t+s}}{N_{t+s}}\right)-\log \left(\frac{Y_{t}}{N_{t}}\right)\right] / s=\frac{1}{1-\alpha}\left[\log A_{t+s}-\log A_{t}\right] / s} \\
& \quad+\frac{\alpha}{1-\alpha}\left[\log \left(\frac{K_{t+s}}{Y_{t+s}}\right)-\log \left(\frac{K_{t}}{Y_{t}}\right)\right] / s+\left[\log \left(\frac{L_{t+s}}{N_{t+s}}\right)-\log \left(\frac{L_{t}}{N_{t}}\right)\right] / s .
\end{aligned}
$$

The first term on the right side of this equation is the contribution to growth of TFP changes, the second is the contribution of changes in the capital-output ratio, and the third is the contribution of changes in hours worked per working-age person. On a balanced-growth path, output per worker and capital per worker grow at the same rate, and the capital-output ratio and hours worked per working-age person are constant. On such a path, our growth accounting would attribute all growth to changes in TFP. In our growth accounting, therefore, the second two terms measure the contributions of deviations from balanced-growth behavior: changes in the investment rate and changes in hours worked per person.

The first column in Table 1 presents the growth accounting for Mexico and Chile during the period 1981-2000. This growth accounting confirms the impression given by comparing Figures 1 and 2. Most of the economic fluctuations in output per working-age person $Y_{t} / N_{t}$ in the two countries were due to changes in total factor productivity $A_{t}$ rather than to changes in the capital-output ratio $K_{t} / Y_{t}$ or in the hours per working-age person $L_{t} / N_{t}$. In Mexico, TFP accounted for a 0.39 fall, compared to 0.25 in the data, during the crisis and stagnation periods 1981-95; it accounted for an increase of 0.13 , compared to an increase of 0.15 in the data, in the recovery period 1995-2000. ${ }^{5}$ In Chile, however, TFP accounted for a fall of 0.19 in the logarithm of output per working-age person, compared to 0.22 in the data, during the crisis period 1981-83; it accounted for an increase of 0.61 , compared to 0.75 in the data, during the recovery period $1983-2000$. 
Mexico and Chile in the 1980s

Table 1. Growth accounting: Decomposition of average annual changes in real output per working-age person (percent)

\begin{tabular}{lrrr}
\hline & \multicolumn{1}{c}{$\begin{array}{c}\text { Model } \\
\text { base case }\end{array}$} & $\begin{array}{c}\text { Model } \\
\text { tax reform }\end{array}$ \\
\hline & \multicolumn{3}{c}{ Mexico } \\
\cline { 2 - 4 } Crisis 1981-87 & & & \\
Change in $Y / N$ & -3.28 & -4.51 & -4.51 \\
$\quad$ due to TFP & -4.73 & -4.73 & -4.73 \\
due to K/Y & 2.09 & 3.07 & 3.07 \\
due to $L / N$ & -0.64 & -2.85 & -2.85
\end{tabular}

Stagnation 1987-95

$\begin{array}{crrr}\text { Change in } Y / N & -0.68 & -1.97 & 0.51 \\ \text { due to TFP } & -1.62 & -1.62 & -1.62 \\ \text { due to } K / Y & 0.76 & 0.43 & 1.06 \\ \text { due to } L / N & 0.18 & -0.77 & 0.05\end{array}$

Recovery 1995-2000

\begin{tabular}{lrrr} 
Change in $Y / N$ & 3.21 & 1.70 & 2.32 \\
due to TFP & 2.71 & 2.71 & 2.71 \\
due to $K / Y$ & -0.78 & -2.47 & -1.88 \\
due to $L / N$ & 1.28 & 1.47 & 1.49 \\
\cline { 2 - 4 } & \multicolumn{3}{c}{ Chile } \\
\cline { 2 - 4 } & & & \\
Crisis 1981- 83 & -11.19 & -11.62 & -11.62 \\
Change in Y/N & -9.68 & -9.68 & -9.68 \\
due to TFP & 5.37 & 6.39 & 6.39 \\
due to K/Y & -6.87 & -8.32 & -8.32 \\
due to $L / N$ & & & \\
& & & \\
Recovery 1983-2000 & & 2.82 & 4.52 \\
Change in $Y / N$ & 4.43 & 3.53 & 3.53 \\
due to TFP & 3.53 & -1.26 & -0.15 \\
due to $K / Y$ & -0.13 & 0.55 & 1.13 \\
due to $L / N$ & 1.03 &
\end{tabular}

\section{Numerical Experiments}

Although growth accounting indicates that most of the changes in output in Mexico and Chile were due to changes in TFP, the contributions of changes in the capital-output ratio and of changes in hours worked per working-age person were not negligible. How much of these changes can we account for 
as equilibrium responses to the observed productivity shocks in a growth model?

To answer this question, we calibrate a simple growth model of a closed economy in which consumers have perfect foresight over the sequence of TFP shocks to Mexico and to Chile. The representative consumer maximizes utility function

$$
\sum_{t=1980}^{\infty} \beta^{t}\left[\gamma \log C_{t}+(1-\gamma) \log \left(\bar{h} N_{t}-L_{t}\right)\right]
$$

subject to the budget constraint in each period,

$$
C_{t}+K_{t+1}-K_{t}=w_{t} L_{t}+\left(1-\tau_{t}\right)\left(r_{t}-\delta\right) K_{t}+T_{t}
$$

and an initial condition on capital, $K_{1980}$. Here $0>\beta>1$ is the discount factor and $0>\gamma>1$ is the consumption share. In addition, $C_{t}$ is consumption, $\bar{h}$ is the number of hours available, taken to be one hundred hours per week, fifty-two weeks per year for working-age persons, and $\left(\bar{h} N_{t}-L_{t}\right)$ is leisure. In addition, $w_{t}$ and $r_{t}$ are the marginal products of the production function with respect to $L_{t}$ and $K_{t}$, and $\tau_{t}$ is the income tax rate on capital income, which we start by assuming fixed - but later lower to mimic the fiscal reforms in Mexico and Chile in the 1980s. $T_{t}$ is a lump-sum transfer that in equilibrium is equal to the tax revenue $\tau_{t}\left(r_{t}-\delta\right) K_{t}$. In Appendix B we show that the qualitative nature of our conclusions is not very sensitive to the specification of the utility function.)

Given the production technology that we have used for growth accounting, the feasibility constraint for this model is

$$
C_{t}+K_{t+1}-(1-\delta) K_{t}=A_{t} K_{t}^{\alpha} L_{t}^{1-\alpha}
$$

Here we include government spending and net exports in consumption. To run numerical experiments, we need to impose values on the parameters $\beta$ and $\gamma$ in the consumer's utility function and on the tax parameter $\tau_{t}$. Using the first-order conditions for the maximization problem of the representative consumer in our model economy, we obtain

$$
\beta=\frac{C_{t}}{C_{t-1}\left[1+\left(1-\tau_{t}\right)\left(r_{t}-\delta\right)\right]}
$$

(10) $\gamma=\frac{C_{t}}{C_{t}+w_{t}\left(\bar{h} N_{t}-L_{t}\right)}$. 
Rather than fix the tax rates in Mexico and Chile and estimate a different discount factor $\beta$ for each country, we fix $\beta=0.98$ in each country and estimate a different average tax parameter $\tau_{t}$ over the period 1960-80. We obtain $\tau_{t}=0.41$ for Mexico and $\tau_{t}=0.56$ for Chile. Our view is that people are fundamentally the same across countries, but that different tax distortions induce different consumption-investment decisions. To find $\gamma$, however, we simply take averages using equation (10) and data from 1960-80. We estimate $\gamma=0.23$ for Mexico and $\gamma=0.28$ for Chile.

It would be equally possible to fix the same value of $\gamma$ in both countries and to estimate different tax distortions to consumption-leisure decisions, like consumption taxes and labor taxes, for each country. Despite some changes in these sorts of taxes in both Mexico and Chile, however, we find that the value of $\gamma$ in (10) does not vary much over the period 1960-2000 in either country. It is worth remembering, however, that our estimates of $\gamma$ implicitly incorporate differences in tax distortions and labor market institutions in the two countries.

The second column in Table 1 and the first columns of graphs in Figures 14 and 15 report the results of our base case numerical experiments. In each country, we set $K_{1980}$ equal to its observed value in 1980 and compute the perfect foresight equilibrium path where the sequence of TFP, $A_{1980}, A_{1981}$, ..., $A_{2000}$ is given by data, and TFP after 2000 is assumed to grow at the same average rate as it did over the period 1960-2000. Notice that for both Mexico and Chile, the model captures that initial decline in output well, but misses from about 1985 on. In particular, it predicts that detrended output in 2000 should be about 20 percent below its value in the data in both countries. In terms of the model's results, it seems equally surprising that Mexico did not do worse in its recovery period and that Chile did so well.

Our discussion of structural reforms in the previous section suggests that changes in taxes may have changed incentives to accumulate capital in both Mexico and Chile. We analyze this possibility by running new numerical experiments in which we introduce tax reform in both countries. Using (9), we estimate that over the period 1988-2000, Mexico had a tax rate of $\tau_{t}=0.09$ and Chile had a tax rate of $\tau_{t}=0.13$. The third column in Table 1 and the second columns of graphs in Figures 14 and 15 report the results of numerical experiments where we compute the equilibrium in which consumers have perfect foresight between 1980 and 1988; they are surprised by a tax reform in 1988 that in Mexico lowers $\tau_{t}$ from 0.41 to 0.10 and in Chile lowers $\tau_{t}$ from 0.56 to 0.10 ; and they have perfect foresight from then on. We impose the same tax reform in both countries to make the point that, although tax reform had significant effects on factor inputs in both countries, it was not differences in these tax reforms that drove the difference in economic performance. 
Figure 14. Numerical experiments for Mexico
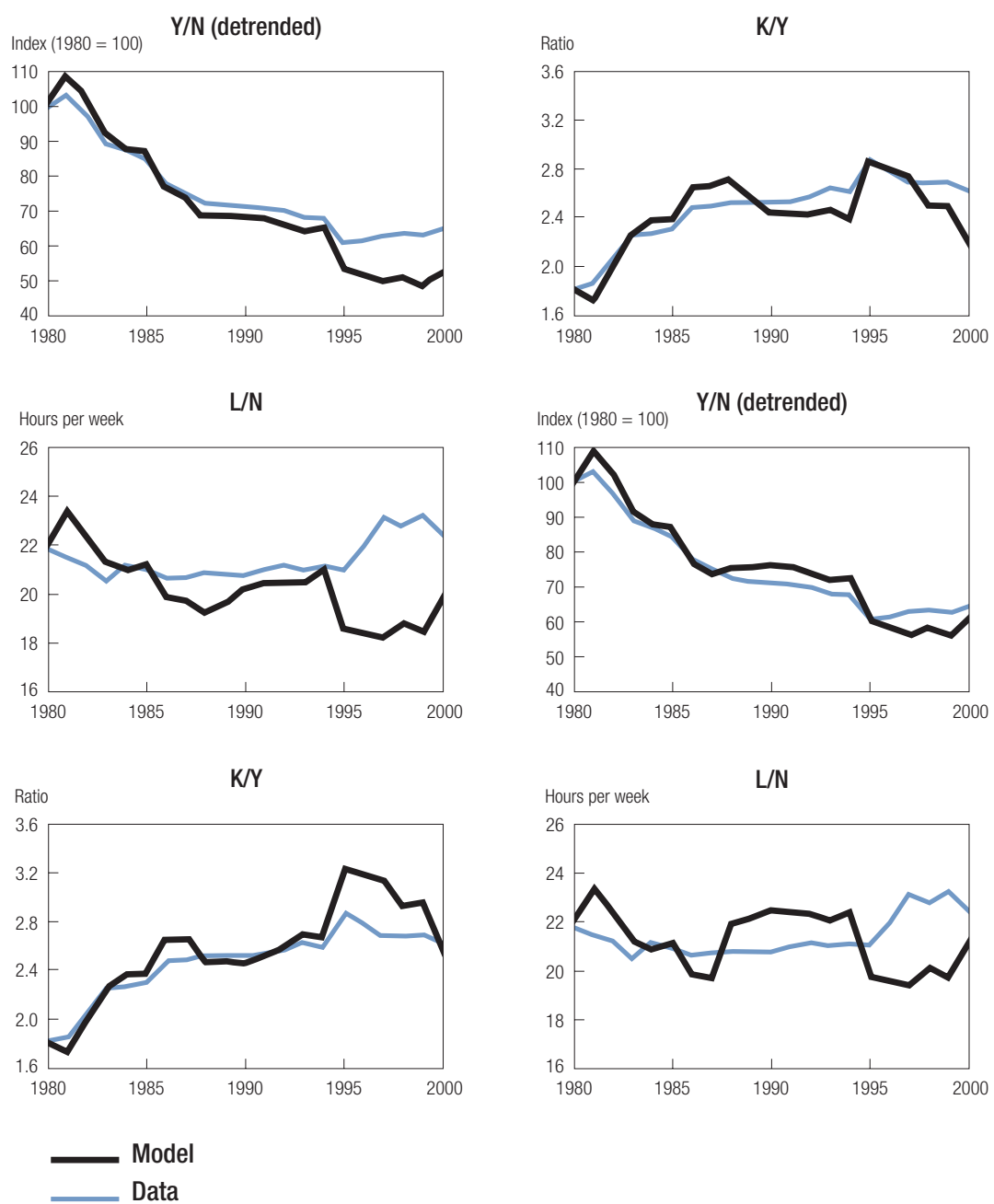

Notice that the model now does an accurate job of accounting for both the crises and the recoveries in Mexico and Chile. Furthermore, there is some direct evidence that the sorts of tax distortions that we have estimated are sensible. In Chile, for example, taxes on firms' income were lowered from 0.46 to 0.10 percent in 1984 ; this tax was increased to 0.15 in 1991 (see Larraín and Vergara 2000). For Mexico, there is no similar simple tax rate to report, but the tax reform in 1987 that allowed firms to deduct the present discounted value of future capital depreciation allowances had a large posi- 
Figure 15. Numerical experiments for Chile
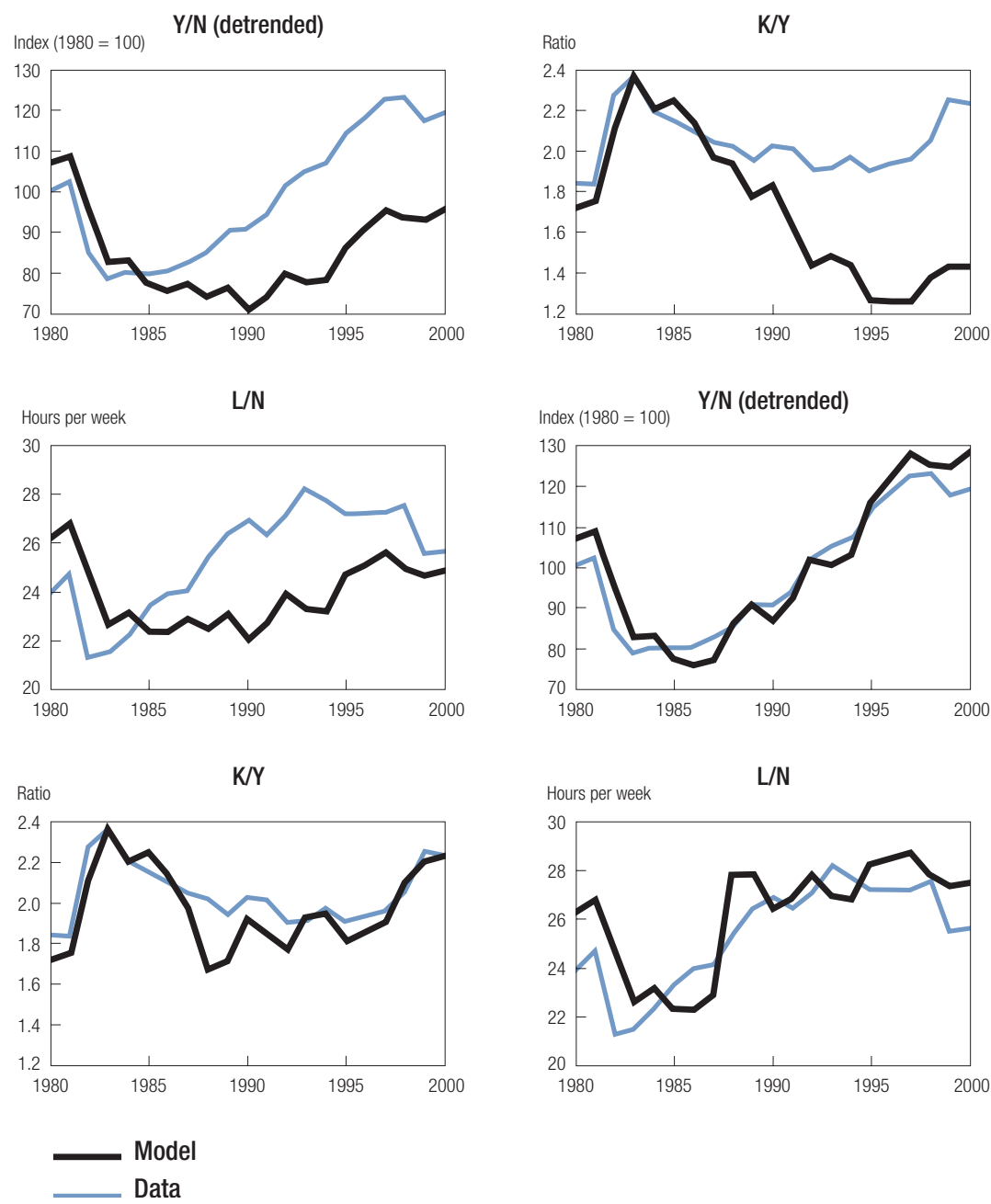

tive impact on incentives to invest. Interestingly, although the tax reform has direct effects only on the incentive to accumulate capital, it increases the incentive to work by raising real wages. ${ }^{6}$

The tax reform that we have imposed on the model is crude and is sure to miss important institutional details and matters of timing. (The results for Chile, for example, look better if we impose the tax reform earlier-when it actually occurred.) Nonetheless, the results of our numerical experiments are striking and the message is clear: changes in tax policy were undoubtedly 
important in both countries, but they cannot explain more than a small fraction of the differences in the recoveries. In both Mexico and Chile, changes in the capital-output ratio and changes in hours worked per working-age person contributed to making the recovery stronger than the base case model predicts. Within the context of our model, the same crude tax reform in both countries can roughly account for these changes in factor inputs. Consequently, to explain the different experiences in Mexico and Chile, we need to explain the different performances of TFP.

\section{How Government Policy Affects TFP}

If TFP movements drove both the initial downturns in Mexico and Chile and the difference in their recoveries, what drove the TFP movements? We think that external shocks initiated the TFP drops and that these drops were magnified by existing government policies that made the financial sectors in both economies fragile. In Mexico, the policy reaction to the initial shocks increased distortions, resulting in a prolonged decline in TFP. In Chile, rapid policy reform led to a recovery of TFP.

Economic theory suggests two obvious mechanisms for the initial TFP drops: (1) Higher real interest rates make some previously profitable investment projects unprofitable and make the capital involved unproductive. Our measure of TFP assumes full utilization of capital and, hence, attributes this drop in utilization to TFP. (2) A deterioration in the terms of trade requires a country to export more to obtain the same quantity of imports, so that more domestic resources are needed to produce the same final output. Hence, in a closed economy model, negative terms of trade shocks manifest themselves as declines in TFP.

While these mechanisms can account for part of the initial TFP drops in both countries, they cannot account for either the severity of these drops or the difference in the recovery paths. In our view, mistakes in government policies made the financial systems in both countries fragile and, hence, exacerbated the effects of the initial external shocks. But what drove the striking difference in the patterns of recovery of TFP seen in Figure 2? Our view is that higher productivity growth in Chile was driven by the timing of privatization and of banking and bankruptcy reforms. Furthermore, given the data on the speed of, and relative importance of, privatization in the two countries, we conjecture that reforms to the banking system and bankruptcy laws were quantitatively more important than privatization in determining the differences in productivity.

Our hypothesis is that, before reforms, government policy distorted the allocations of resources both within and across sectors in Mexico and Chile, pushing the economies inside their aggregate production possibility fron- 
tiers. As reforms were implemented, first in Chile and later in Mexico, each economy moved closer to its production possibility frontier. Here we propose a theory of how distortions in the financial system and poorly designed bankruptcy laws can have negative effects on productivity. We first describe the static effects of distortions on allocations of resources and then describe the dynamic effects on the entry and exit decisions of firms.

Before we turn to our theory, however, let us contrast our hypothesis with a potential explanation for measured productivity movements that is common in the business cycle literature (see, for example, Burnside, Eichenbaum, and Rebelo 1993). This explanation is that unobserved movements in factor utilization cause large movements in measured productivity. Although this mechanism can have some effect at the onset of a crisis, as we have pointed out, we argue here that it cannot explain large and increasing differences in productivity over periods longer than a decade.

To make this mechanism concrete, suppose that aggregate output $Y$ is produced according to the Cobb-Douglas function

$$
Y=A(u K)^{\alpha}(e L)^{1-\alpha}
$$

where $0 \leq u \leq 1$ is unobserved capacity utilization of capital and $0 \leq e \leq 1$ is unobserved labor effort. It is important to note that variations in $e$ do not correspond to variations in the employment rate, the participation rate, or average hours worked: if these variations are properly measured, they show up as variations in $L$. If we observe $K$ and $L$ in the data and do not observe $u$ or $e$, we would identify movements in $u^{\alpha} e^{1-\alpha}$ as changes in productivity instead of identifying them as movements in factor utilization. In our growth accounting exercise, for example, we have used $L / N$ to measure hours worked per person, but we ideally should have used $e L / N$.

Such shifts in utilization may play a role in the initial phase of the crisis. It seems far-fetched, however, to argue that they can account for large differences in productivity movements between countries over a period of a decade or more, when firms are making new investments and hiring new workers. Indeed, in Mexico, the country with falling productivity, the story would have to be that, at the same time that the average firm in Mexico was gradually lowering its utilization rate of capital, it was investing in new capital. Similar comments apply to labor: at the same time firms were supposedly "hoarding" labor by requiring low effort, on average, they were hiring new workers. This type of behavior is inconsistent with that of firms in the standard growth model.

One could imagine a richer model in which some firms were underutilizing factors and hiring no new factors at the same time that others were utilizing 
factors fully and hiring new factors. Even so, it is hard to imagine that this situation could have persisted and even worsened for as long as a decade. Presumably, during that long a period, the depreciation of physical capital and the natural turnover of workers would have gradually raised the utilization rates, not persistently lowered them.

\section{Static Effects of Policy}

A government's favored treatment of certain sectors can interfere with the market mechanism, leading to a static misallocation of resources and lower aggregate productivity. To see this in the simplest possible example, consider an economy with two sectors in which labor $L_{i}$ produces a homogeneous output good $Y_{i}$ according to the production function $Y_{i}=A_{i} L_{i}^{\alpha}, i=1$, 2. For simplicity, set $A_{1}=A_{2}=1$. The aggregate resource constraint is $L_{1}+L_{2}=L$.

Before the reform, sector 1 is the government enterprise sector that is subsidized at rate $\tau_{1}$, and sector 2 is the private sector that is taxed at rate $\tau_{2}$. Any residual from the taxes and subsidies is financed with lump-sum taxes or transfers. A competitive labor market equates the marginal products of labor in the two sectors, which implies that

$$
\frac{L_{1}}{L_{2}}=\left(\frac{1+\tau_{1}}{1-\tau_{2}}\right)^{\frac{1}{1-\alpha}}
$$

Substituting the allocations of labor back into the resource constraint and solving yields

$$
Y\left(\tau_{1}, \tau_{2}\right)=\frac{1+\left(\frac{1+\tau_{1}}{1-\tau_{2}}\right)^{\frac{\alpha}{1-\alpha}}}{\left[1+\left(\frac{1+\tau_{1}}{1-\tau_{2}}\right)^{\frac{1}{1-\alpha}}\right]^{\alpha}} L^{\alpha}
$$

Now imagine a privatization that sets both the subsidy and the tax to zero. The efficient allocation of labor would be $L_{i}=L / 2$ and the aggregate output would be $Y(0,0)=2^{1-\alpha} L^{\alpha}$. Relative to the efficient allocation, before reform the government enterprise in sector 1 produces too much output, and the private firm in sector 2, too little output. Overall, output is lower in the economy before reform than it is afterward. If $\alpha=3 / 4$ and $\tau_{1}=\tau_{2}=1 / 3$, for example, then output in the distorted economy is about 10 percent less 
than in the undistorted economy. Consequently, productivity would rise with the reform.

This example illustrates how distortions can affect the static aggregate production possibility frontier. We have focused on a direct subsidy, but any differential treatment of one sector over another will have a similar impact. It illustrates how, in theory, different paths for privatization in the two countries can lead to different paths for aggregate productivity.

In terms of the data, the timing of the privatization in the two countries does not match up well with the differences in productivity. This makes it doubtful that privatization can be the main force that accounts for the different productivity paths. During the period 1987-95, Mexico was stagnating and Chile was growing. In Mexico, privatization was vigorously under way, whereas in Chile, most privatization had already occurred well before this time. Consequently, unless there are long lags between changes in incentives and changes in the allocation of resources, this story will not work. Galal et al. (1994) and La Porta and Lopez-de-Silanes (1999) estimate that improvements in productivity were achieved very rapidly in privatized firms in Mexico and Chile.

Reforms in the banking sector can also reduce static inefficiencies similar to those in the privatization story above. Suppose that, before banking reform, the government chooses some firms or sectors to favor with low-interest-rate loans. Holding fixed the return on deposits, these lower interest rates for one sector must be paid either by higher rates in the unfavored sector or by transfers to the banking system from the government.

Consider a model in which, for simplicity, we suppress labor and let the production functions be given by $A_{i} K_{i}^{\alpha}, i=1,2$. Sector 1 receives a proportional subsidy of $\tau_{1}$ on the interest rate that it pays on loans, and sector 2 pays a tax $\tau_{2}$. The first-order conditions for profit maximization are

$$
\frac{\alpha A_{1} K_{1}^{\alpha-1}}{\left(1-\tau_{1}\right)}=\frac{\alpha A_{2} K_{2}^{\alpha-1}}{\left(1+\tau_{2}\right)}=r
$$

We can think of these subsidies and taxes as being accomplished through preferential lending by banks. Any net revenues that are needed are supplied to the banks using lump-sum taxes or transfers. The relative allocations of capital are given by

$$
\frac{K_{1}}{K_{2}}=\left(\frac{A_{1}}{A_{2}}\right)^{\frac{1}{1-\alpha}}\left(\frac{1+\tau_{2}}{1-\tau_{1}}\right)^{\frac{1}{1-\alpha}}
$$


In contrast to the efficient outcome, a higher fraction of the capital stock is allocated to the subsidized sector than is warranted by the differences in productivity. For a fixed level of total capital, these distortions lower the amount of output due to sectoral misallocations, as in the first example. If these distortions decrease the incentives to make loans, as they did in Mexico, then they can also lead to a lower level of overall capital and have an additional negative effect on output.

Despite the static nature of the inefficiency, this story has potential for explaining the differences in TFP performance. In Mexico, until at least the early 1990s, the banking system remained nationalized, gave subsidized loans to some firms, and rationed loans to others. In contrast, banking reform was the major reform that Chile had done poorly in the 1970s and had to redo in the 1980s. See the work of Galvez and Tybout (1985) for a description of the sort of preferential lending arrangements that existed for some firms, but not others, in Chile before the crisis.

\section{Dynamic Effects of Policy}

One way that distortions in the financial system and poorly designed bankruptcy laws can lead to lower aggregate productivity is by discouraging poorly performing firms from exiting from production. By keeping firms operating that otherwise would have exited, these distortions and bankruptcy laws can prevent new potentially productive firms from entering.

The models developed by Atkeson and Kehoe (1995) and Chu (2001) can be used to address such issues. In these models, new firms enter with the newest technology, stochastically learn over time, and then exit when their prospects for further productivity improvements are poor. In such models, any policy that interferes with the natural birth, growth, and death of production units based on prospective productivities can move the economy further and further inside the production possibility frontier and will show up as a decrease in measured productivity. Simulations by Chu (2001) indicate that these dynamic distortions can have enormous effects over time.

To get some idea of how this sort of model works, consider Atkeson and Kehoe's (1995) model in which production is done in a continuum of plants. Each plant has its own level of productivity $A$ and is operated by a manager. A plant with productivity $A$ has the production function $y=A^{1-v}\left(k^{\alpha} l^{1-\alpha}\right)^{v}$. The manager's span of control parameter, $v<1$, determines the degree of diminishing returns at the plant level. A manager who decides to operate a plant chooses capital $k$ and labor $l$ to maximize static returns

$$
d_{t}(A)=\max _{k, l} A^{1-v}\left(k^{\alpha} l^{1-\alpha}\right)^{v}-r_{t} k-w_{t} l-w_{t}^{m}
$$


where $w_{t}^{m}$ is the manager's opportunity cost of not working or starting another plant. Let the solutions be denoted $k_{t}(A)$ and $l_{t}(A)$. For a given distribution $\lambda_{t}(A)$ of productivities across plants, it is easy to show that aggregate output is given by $Y_{t}=\bar{A}_{t}^{1-v} K_{t}^{\alpha} L_{t}^{1-\alpha}$, where

$$
\bar{A}_{t}=\int_{A} A \lambda_{t}(d A)
$$

is aggregate productivity and $K_{t}=\int_{A} k_{t}(A) \lambda_{t}(d A)$ and $L_{t}=\int_{A} l_{t}(A) \lambda_{t}(d A)$ are aggregate capital and labor. That is, aggregate productivity depends on the mean of the productivities of all of the plants that are in operation.

Over time, the productivity of each plant evolves stochastically: a plant with productivity $A$ at $t$ has random productivity $A \varepsilon$ at $t+1$, where the shock $\varepsilon$ is drawn from a probability distribution $\pi(\varepsilon)$. The crucial decision for the manager of whether or not to operate a plant is dynamic and is described by the Bellman equation

$$
\begin{aligned}
& V_{t}(A)=\max \left[0, V_{t}^{o}(A)\right], \\
& \text { where } V_{t}^{o}(A)=d_{t}(A)+\frac{1}{1+r_{t}} \int_{\varepsilon} V_{t+1}(A \varepsilon) \pi(d \varepsilon) .
\end{aligned}
$$

Here $V_{t}^{o}(A)$ is the value if the plant is operated in the current period, and $V_{t}(A)$ is the maximum of the returns from either closing the plant or operating it. New plants can enter according to a similar process. The outcome of all the managerial decisions to operate or not is a new distribution $\lambda_{t+1}(A)$ over productivities in period $t+1$.

So far we have described a simple version of the model in which the probability distribution $\pi(\varepsilon)$ that generates shocks to plant-specific productivity does not change with plant age. In the U.S. data examined by Atkeson and Kehoe (1995), the labor employed and output produced by a cohort of plants tend to start low when the plants are young, grow for the next twenty years or so, and then gradually decline. Cahmi, Engel, and Micco (1997) present similar data for evidence from Chile. To capture this sort of pattern, Atkeson and Kehoe modify the model. They add a frontier level of new technology that grows over time, and they allow the mean value of shocks to the productivity of a plant to increase and then decrease. In the model, new plants start with the newest technology but with little specific knowledge on how to use it. Over time, these plants build up their specific knowledge and grow as they draw shocks to productivity from a distribution with an increasing mean. After twenty years or so, the mean of the shocks $\varepsilon$ starts to fall as the 
learning process slows. Plants then decline in size and eventually exit.

Now consider the effects of a distortion in the financial system in which the government encourages the banks to lend at a subsidized rate $r_{1 t}=r_{t}\left(1-\tau_{1 t}\right)$ to firms (identified with plants in the model) in sector 1 and to lend to other firms at a relatively high rate $r_{2 t}=r_{t}\left(1+\tau_{2 t}\right)$. The favored firms discount the future less than the unfavored ones. Substituting these distorted interest rates into the Bellman equation (18) produces different solutions to the managers' dynamic programming problems in sectors 1 and 2. In particular, favored firms will choose to continue to operate in situations where unfavored firms would choose to shut down: even if a favored firm experiences a low productivity $A$, it will be more prone than an unfavored firm to borrow to cover losses and to continue operating, hoping for a favorable shock $\varepsilon$ to increase its productivity in the future.

Consider next the effects of inefficient bankruptcy procedures that make it difficult for firms to exit or that subsidize the losses of firms to keep them operating. This distortion causes firms to keep operating for longer than they would have with no distortions.

Together, distortions in the financial system and bankruptcy procedures change the mix of firms that operate in the economy, leading to the inefficiency of many low-productivity firms continuing. This leads to a lower value of aggregate productivity $\bar{A}$.

How would the removal of these distortions affect the path of productivity over time? Some effects would be immediate. Upon removal, some previously favored firms that would have continued will fail, and some unfavored firms that would have failed will continue. The subtler, and potentially more important, effects take more time to show up in aggregates. The removal of distortions would encourage new firms to enter. Such new firms would have the newest technologies but would build up their organization-specific productivity only slowly over time. Consequently, removing these distortions would show up with a lag in the aggregate productivity statistics.

Levinsohn and Petrin (1999) present evidence that most of the increase in productivity in manufacturing in Chile in the mid-1980s was due to the exit of inefficient firms and expansion of efficient firms - rather than to within-firm productivity increases. This sort of evidence provides crucial micro evidence for our story of the role of reforms in banking and bankruptcy. It would also be useful to obtain micro data on bank loans and bankruptcies, especially in Mexico. As it stands, the data in Figures 12 and 13 provide only circumstantial evidence. Our theory also provides an important role for barriers to entry of new firms. Djankov et al. (2000) provide evidence that such barriers are much higher in Mexico than they are in Chile. What we need to look for is evidence on how these barriers changed during the 1980s and 1990s. 


\section{Concluding Remarks}

The sort of lag between government policy change and the resulting change in productivity discussed in the previous section may, in fact, suggest major roles for Chile's trade reforms and privatization in the 1970s in explaining productivity increases a decade or more later. Clerides et al. (1998) and Pavcnik (2000), for example, present micro evidence that trade liberalization and export growth in Mexico and Chile caused inefficient firms to exit and efficient firms to grow. Openness to foreign direct investment and deregulation in domestic industry - once again, reforms that took place in Mexico later than in Chile - may also have played significant roles. In Mexico, foreign direct investment only grew from 1.5 percent in 1983 to 3.3 percent in 1995, whereas in Chile it grew from 0.7 percent of GDP to 4.5 percent during that same time period.

To disentangle the dynamic effects of these reforms on productivity and output from the effects of banking and bankruptcy reforms, more work is needed. The tasks for the future are to collect more micro data, build a quantitative model that incorporates the theoretical structure sketched out in the previous section, and calibrate that model to Mexico and Chile. The challenge is to use the same model to explain why Mexico stagnated while Chile boomed. This paper provides clear directions that indicate where the explanations can and cannot be.

\section{Appendix A: Data Sources}

\section{Data Cited in Text}

The data on current account deficits, LIBOR, and nominal exchange rates are from the International Monetary Fund's International Financial Statistics (IFS). The data on crude petroleum and copper exports in 1960 are from the United Nations' International Trade Statistics Yearbook; these same data for 2000 are from the Web sites of the Banco Central de Chile (http://si2.bcentral.cl/basededatoseconomicos) and Mexico's Instituto Nacional de Estadística Geografía e Informática (http:// dgcnesyp.inegi.gob.mx). The information on the exports of CODELCO in 2000 is from the Web site of the Comisión Chilena del Cobre (http://www.cochilco.cl). The data on the fraction of total external debt that is public or publicly guaranteed is from the World Bank's World Development Indicators 2001 (WDI) CD-ROM. The information on the fraction of GDP generated by government enterprises is from $W D I$. The information on foreign direct investment is from IFS.

\section{Data for Growth Accounting}

The GDP series are from IFS. The investment series used to compute the capital stocks are the sum of gross fixed capital formation and change in inventories reported by IFS. We have data on both GDP and investment for 1950-2000 for Mexico and 
1960-2000 for Chile. The labor series have been estimated using data from a number of sources. The labor inputs for both countries are the products of total employment and a survey of average hours per worker. For Mexico, total employment for 1980 to 1990 is total employment from the Penn World Table 5.6. Employment from 1991-2000 is taken from the OECD. Average hours worked for 1991-2000 is from the OECD. This series is spliced with data on average hours worked in manufacturing for 1960-91 from the OECD. The labor series for Chile is calculated using data on total employment from the Penn World Table 5.6 from 1980-85 and total employment reported in IFS from 1985-2000. The hours series is Average Hours Worked in Urban Santiago from the survey Encuesta de Ocupación y Desocupación released quarterly by the Departamento de Economía, Universidad de Chile.

Figure 1. The real GDP series are indexes of real GDP volume from IFS. The population aged 15-64 is from WDI. These data end in 1999.

Figure 3. The data are from IFS: the price of copper is the London price, while the price of oil reported is the average world price. Both series are deflated using the U.S. PPI from $I F S$.

Figure 4. All the data are from IFS. Money is defined as the sum of currency outside deposit money banks and demand deposits other than those of the central government.

Figure 5. The real wage in manufacturing for Mexico was created by splicing a series reported by IFS with a series from the OECD's Main Economic Indicators. The IFS series is deflated using the CPI reported by IFS. The OECD series is a real series. These series are spliced using their ratio in 1995. The real manufacturing wage in Chile is a series reported in Indicadores Mensuales de Empleo y Remuneraciones from Chile's Instituto Nacional de Estadísticas.

Figure 6. The real exchange rates are calculated using period averages of the nominal exchange rates and Consumer Price Indexes from IFS.

Figure 7. The series are the ratios of nominal imports and exports and nominal GDP from $I F S$.

Figure 8. The U.S. PPI is from IFS. The export values in U.S. dollars are from WDI and the World Trade Organization's International Trade Statistics 2000.

Figure 9. Total external debt for 1980-2000 is from WDI. The GDP series are from IFS and are converted into U.S. dollars using period average nominal exchange rates from $I F S$.

Figure 10. Nominal investment and nominal GDP are from IFS.

Figure 11. Government surplus is from IFS.

Figure 12. Both the private credit and GDP series are from IFS. Private Credit is the sum of claims on Non-Financial Public Enterprise and Claims on Private Sector.

Figure 13: The data on bankruptcies in Chile correspond to the number of new filings, not the number of resolutions; the Fiscalía Nacional de Quiebras of the Ministerio de Justicia provided the authors with these data on request. Unfortunately, data on the revenue of bankrupt firms were not available. 


\section{Appendix B: Sensitivity Analysis}

Tables 2 and 3 present the growth accounting and numerical experiments for alternative specifications of the model.

Table 2 presents the results for a specification of the model with the sort of large capital share suggested by Mexico's and Chile's national accounts, $\alpha=0.60$, and for a second specification with the sort of high depreciation rate suggested by Chile's national accounts, $\delta=0.08$ for the period 1981-2000. The growth accounting and

Table 2. Sensitivity analysis: Alternative production technologies average annual change in real output per working-age person (percent)

\begin{tabular}{|c|c|c|c|c|c|c|}
\hline & \multicolumn{3}{|c|}{$\alpha=0.60$} & \multicolumn{3}{|c|}{$\delta=0.08$} \\
\hline & Data & $\begin{array}{c}\text { Model } \\
\text { base case }\end{array}$ & $\begin{array}{l}\text { Model } \\
\text { tax reform }\end{array}$ & Data & $\begin{array}{c}\text { Model } \\
\text { base case }\end{array}$ & $\begin{array}{c}\text { Model } \\
\text { tax reform }\end{array}$ \\
\hline & \multicolumn{6}{|c|}{ Mexico } \\
\hline \multicolumn{7}{|l|}{ Crisis $1981-87$} \\
\hline Change in $Y / N$ & -3.28 & -2.64 & -2.64 & -3.28 & -4.14 & -4.14 \\
\hline due to TFP & -9.94 & -9.94 & -9.94 & -4.43 & -4.43 & -4.43 \\
\hline due to $K / Y$ & 7.30 & 9.16 & 9.16 & 1.79 & 2.61 & 2.61 \\
\hline due to $L / N$ & -0.64 & -1.86 & -1.86 & -0.64 & -2.32 & -2.32 \\
\hline \multicolumn{7}{|c|}{ Stagnation 1987-95 } \\
\hline Change in $Y / N$ & -0.68 & -1.62 & -1.03 & -0.68 & -1.69 & -0.50 \\
\hline due to TFP & -3.52 & -3.52 & -3.52 & -1.46 & -1.46 & -1.46 \\
\hline due to $K / Y$ & 2.66 & 2.67 & 2.63 & 0.60 & 0.31 & 0.92 \\
\hline due to $L / N$ & -0.18 & -0.76 & 0.14 & 0.18 & -0.54 & 0.04 \\
\hline \multicolumn{7}{|c|}{ Recovery 1995-2000 } \\
\hline Change in $Y / N$ & 3.21 & 1.19 & 2.20 & 3.21 & 1.50 & 2.12 \\
\hline due to TFP & 4.65 & 4.65 & 4.65 & 2.82 & 2.82 & 2.82 \\
\hline due to $K / Y$ & -2.72 & -4.42 & -3.40 & -0.89 & -2.53 & -2.06 \\
\hline \multirow[t]{2}{*}{ due to $L / N$} & 1.28 & 0.97 & 0.96 & 1.28 & 1.21 & 1.36 \\
\hline & \multicolumn{6}{|c|}{ Chile } \\
\hline \multicolumn{7}{|l|}{ Crisis 1981-83 } \\
\hline Change in $Y / N$ & -11.19 & -10.66 & -10.66 & -11.19 & -10.72 & -10.72 \\
\hline due to TFP & -23.10 & -23.10 & -23.10 & -9.68 & -9.68 & -9.68 \\
\hline due to $K / Y$ & 18.79 & 20.14 & 20.14 & 5.36 & 6.43 & 6.43 \\
\hline due to $L / N$ & -6.87 & -7.70 & -7.70 & -6.87 & -7.48 & -7.48 \\
\hline \multicolumn{7}{|c|}{ Recovery $1983-2000$} \\
\hline Change in $Y / N$ & 4.43 & 1.56 & 3.83 & 4.43 & 2.52 & 4.29 \\
\hline due to TFP & 3.86 & 3.86 & 3.86 & 3.34 & 3.34 & 3.34 \\
\hline due to $K / Y$ & -0.46 & -2.65 & -0.93 & 0.06 & -1.21 & 0.00 \\
\hline due to $L / N$ & 1.03 & 0.34 & 0.89 & 1.03 & 0.39 & 0.95 \\
\hline
\end{tabular}


the numerical exercises still indicate that it is mostly fluctuations in TFP that account for the different growth paths of Mexico and Chile. When we use $r_{t}=\alpha Y_{t} / K_{t}$ to calculate (before) tax rates of return on capital for the period 1960-2000, we find that the specification with $\alpha=0.60$ is unattractive because it implies rates that are implausibly high, averaging over 25 percent in both countries. These returns are out of line with the sorts of real interest rates found in the International Monetary Fund's International Financial Statistics. Similarly, when we use equation (3) to calculate a series for the capital stock, we find that the specification with $\delta=0.08$ is unattractive because it implies implausibly low capital-output ratios, averaging 1.59 in Mexico and 1.45 in Chile over the period 1960-2000. Both specifications require unattractive calibrations of capital taxes. For the specification with $\alpha=0.60$, we estimate $\tau_{t}=$ 0.77 in Mexico and $\tau_{t}=0.82$ in Chile during the period 1960-80, and $\tau_{t}=0.67$ in Mexico and $\tau_{t}=0.70$ in Chile during the period 1988-2000. In the numerical experiments with a tax reform, we lower $\tau_{t}$ to 0.68 in both countries in 1988. For the specification with $\delta=0.08$, we estimate $\tau_{t}=0.47$ in Mexico and $\tau_{t}=0.51$ in Chile during the period 1960-80, and $\tau_{t}=0.15$ in Mexico and $\tau_{t}=0.26$ in Chile during the period 1988-2000. In the experiments with a tax reform, we lower $\tau_{t}$ to 0.20 in 1988. For the specification with $\alpha=0.60$, we need to recalibrate $\gamma$. It is 0.34 in Mexico and 0.41 in Chile.

Table 3 presents the results for specifications of the model that use the utility function

$$
\sum_{t=1980}^{\infty} \beta^{t} \tilde{N}_{t}^{\eta}\left(\left[\left(\frac{C_{t}}{\tilde{N}_{t}}\right)^{\gamma}\left(\frac{N_{t}-L_{t}}{N_{t}}\right)^{1-\gamma}\right]^{\phi}-1\right) / \phi
$$

Here $\tilde{N}_{t}$ is an adult equivalent measure of population that puts weight $1 / 2$ on persons not of working age and weight 1 on working-age persons. The utility function used in the paper is, of course, the special case where $\phi=\eta=0$. The second and third columns of Table 3 report the results of numerical experiments where $\phi=-1$ and $\eta=0$. The fourth and fifth columns report the results of experiments where $\phi=0$ and $\eta=1$. Because neither specification changes the production technology, the growth accounting stays the same as that in Table 1 . For the specification with $\phi=-1$, we estimate $\tau_{t}=0.36$ in Mexico and $\tau_{t}=0.52$ in Chile during the period 1960-80, and $\tau_{t}=0.05$ in Mexico and $\tau_{t}=-0.02$ in Chile during the period 1988-2000. In the experiments with a tax reform, we lower $\tau_{t}$ to 0.04 in 1988. For the specification with $\eta=1$, we estimate $\tau_{t}=0.67$ in Mexico and $\tau_{t}=0.75$ in Chile during the period 1960-80, and $\tau_{t}=0.44$ in Mexico and $\tau_{t}=0.32$ in Chile during the period 1988-2000. In the experiments with a tax reform, we lower $\tau_{t}$ to 0.40 in 1988.

The numerical experiments still indicate that the differences in TFP paths account for most of the differences in the economic performances of Mexico and Chile. Notice, however, that for those experiments reported in Table 3, the model with the tax reform does not account for all of Chile's recovery. Since there are large discrepan- 
Mexico and Chile in the 1980s

Bergoeing et al.

Table 3. Sensitivity analysis: Alternative utility functions average annual change in real output per working-age person (percent)

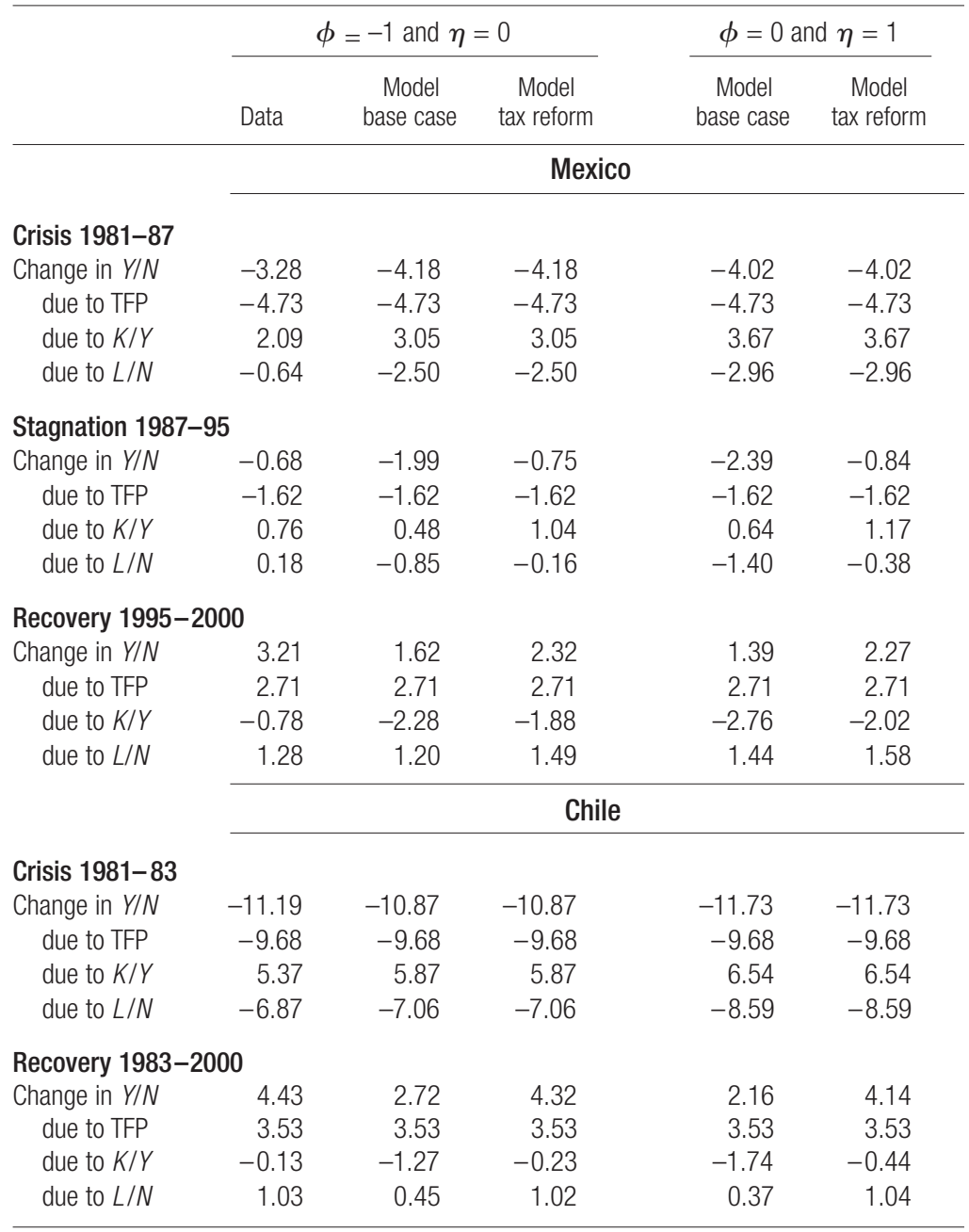

cies between the estimated capital income tax rate $\tau_{t}$ for Mexico and Chile over the period 1988-2000, imposing the Mexican tax rate on Chile does not do as well as it does for the experiment reported in Table 1. 
Notes

Reprinted from Review of Economic Dynamics, Vol. 5, Raphael Bergoeing, Patrick J. Kehoe, Timothy J. Kehoe, and Raimundo Soto, "A Decade Lost and Found: Mexico and Chile in the 1980s," pages 166-205, copyright 2002, with permission from Elsevier. The original version of this paper appeared in September 2001 as Staff Report 292, Federal Reserve Bank of Minneapolis.

We would like to thank the participants at the Minneapolis Fed's "Great Depressions of the Twentieth Century" conference-especially Pete Klenow-and participants at seminars at the Centre de Recerca de Economia de Benestar and the East-West Center for helpful comments. We are also grateful to Edgardo Barandiarán, V. V. Chari, Bob Lucas, Rolf Luders, Art Rolnick, Jaime Serra-Puche, and especially Ed Prescott, for useful discussions. Jim MacGee, Kim Ruhl, Mark Gibson, and Ananth Ramanarayanan provided invaluable research assistance. Bergoeing thanks the Hewlett Foundation, Kehoe and Kehoe thank the National Science Foundation, and Soto thanks the Banco Central de Chile for research support. The data used in this paper are available at http://www.econ.umn.edu/ tkehoe/.

1. Throughout we focus on output per working-age person - which is appropriate for our growth accounting and our model — rather than output per capita — which is not appropriate. Since both Mexico and Chile went through demographic transitions during 1960-2000 in which population growth rates fell sharply, the percentage of working-age persons in the total population changed, and these two measures of output do not move proportionately.

2. To detrend the GDP data in Figure 1, we use a common 2 percent growth rate, which comes close to matching both Mexico's and Chile's average annual growth rates over our entire sample, 1960-2000.

3. It would obviously be useful to collect more data on bankruptcies in Chile and, especially, Mexico. It is telling, however, that no data comparable to those in Figure 13 seem to exist in Mexico.

4. The calculation of the capital stock series here differs slightly from that in the work of Bergoeing et al. (2002), which explains the minor differences in our growth accounting and numerical experiments.

5. In interpreting our results, remember that we are using logarithmic approximations to growth rates, which are accurate for small rates but not for large ones. The logarithmic approximation says, for example, that Mexico's output per working-age person grew by $16.05(=5 \times 3.21)$ percent between 1995 and 2000 ; it actually grew by 17.41 percent $\left(e^{0.1605}=\right.$ $1.1741)$. On the other hand, the logarithmic approximation says that Chile's output per working-age person grew by $75.35(=17 \times 4.43)$ percent between 1983 and 2000; it actually grew by 112.45 percent $\left(e^{0.7535}=2.1245\right)$. The major advantage of using logarithms is that they allow us to do an additive decomposition of the determinants of growth.

6. Notice that the model overpredicts hours worked in the early 1980s in both countries, both before and during the crisis. This is not a matter of secular trends. Remember that we have calibrated the crucial parameter, $\gamma$, for determining hours worked to data from the 1960s and 1970s. Hours worked per working-age person were, in fact, low by historical standards during the early 1980 s in both countries. 


\section{References}

Aspe, Pedro. 1993. Economic transformation the Mexican way. Cambridge, MA: MIT Press.

Atkeson, Andrew, and Patrick J. Kehoe. 1995. Industry evolution and transition: Measuring investment in organization capital. Staff Report 201. Federal Reserve Bank of Minneapolis.

Barandiarán, Edgardo, and Leonardo Hernández. 1999. Origins and resolution of a banking crisis: Chile 1982-86. Working Paper 57. Banco Central de Chile.

Bergoeing, Raphael; Patrick J. Kehoe; Timothy J. Kehoe; and Raimundo Soto. 2002. A decade lost and found: Mexico and Chile in the 1980s. Review of Economic Dynamics 5 (January): 166-205.

Bosworth, Barry; Rudiger Dornbusch; and Raul Labán, eds. 1994. The Chilean economy: Policy lessons and challenges. Washington, DC: Brookings Institution.

Burnside, Craig; Martin Eichenbaum; and Sergio Rebelo. 1993. Labor hoarding and the business cycle. Journal of Political Economy 101 (April): 245-73.

Cahmi, Alexis; Eduardo Engel; and Alejandro Micco. 1997. Dinámica de empleo y productividad en manufacturas: Evidencia micro y consecuencias macro. In Análisis empírico del crecimiento en Chile, ed. Felipe G. Morandé and Rodrigo Vergara, 197-225. Santiago: CEP-ILADES/Georgetown University.

Chu, Tianshu. 2001. Exit barriers and economic stagnation. Manuscript. East-West Center.

Clerides, Sofronis; Saul Lach; and James R. Tybout. 1998. Is "learning-by-exporting” important? Micro-dynamic evidence from Colombia, Mexico, and Morocco. Quarterly Journal of Economics 113 (3): 903-47.

Corbo, Vittorio. 1985. Reforms and macroeconomic adjustments in Chile during 1974-84. World Development 13: 893-916.

Corbo, Vittorio, and Stanley Fischer. 1994. Lessons from the Chilean stabilization and recovery. In The Chilean economy: Policy lessons and challenges, ed. Barry P. Bosworth, Rudiger Dornbusch, and Raul Labán, 29-67. Washington, DC: Brookings Institution.

De la Cuadra, Sergio, and Dominique Hachette. 1991. Liberalizing foreign trade: Chile. In Liberalizing foreign trade. Vol. 1, The experience of Argentina, Chile, and Uruguay, ed. Demetris Papageorgiou, Michael Michaely, and Armeane Choksi, 169-319. Cambridge, MA: Basil Blackwell.

Djankov, Simeon; Rafael La Porta; Florencio Lopez-de-Silanes; and Andrei Shleifer. 2000. The regulation of entry. Working Paper 7892. National Bureau of Economic Research.

Edwards, Sebastian. 1998. Two crises: Inflationary inertia and credibility. Economic Journal 108 (448): 680-702.

Edwards, Sebastian, and Alejandra Cox Edwards. 1991. Monetarism and liberalization: The Chilean experiment. 2nd ed. Cambridge, MA: Harper and Row.

Friedman, Milton, and Anna J. Schwartz. 1963. A monetary history of the United States, 1867-1960. Princeton, NJ: Princeton University Press. 
Galal, Ahmed; Leroy Jones; Pankaj Tandon; and Ingo Vogelsang. 1994. Welfare consequences of selling public enterprises: An empirical analysis. New York: Oxford University Press for the World Bank.

Galvez, Julio, and James Tybout. 1985. Microeconomic adjustments in Chile during 1977-1981: The importance of being a grupo. World Development 13 (8): 969-94.

García-Verdú, Rodrigo. 2005. Factor shares from household survey data. Working paper 200505. Banco de México.

Glade, William. 1996. Privatization: Pictures of a process. In Bigger economies, smaller governments: Privatization in Latin America, ed. Rossana Corona and William Glade, 3-24. New York: HarperCollins.

Gollin, Douglas. 2002. Getting income shares right. Journal of Political Economy 110 (2): 458-74.

Gruben, William, and John H. Welch. 1996. Distortions and resolutions in Mexico's financial system. In Changing structure of Mexico: Political, social, and economic prospects, ed. Laura Randall, 63-75. London: Sharpe.

Hachette, Dominique, and Rolf Luders. 1993. Privatization in Chile. San Francisco: International Center for Economic Growth/ICS Press.

Hayashi, Fumio, and Edward C. Prescott. 2002. The 1990s in Japan: A lost decade. Review of Economic Dynamics 5 (January): 206-35.

Hsieh, Chang-Tai, and Jonathan A. Parker. 2001. Taxes and growth in a financially underdeveloped country: Explaining the Chilean investment boom. Manuscript. Princeton University.

Kehoe, Timothy J. 1995. A review of Mexico's trade policy from 1982 to 1994. World Economy 18 (Autumn): 135-51.

La Porta, Rafael, and Florencio Lopez-de-Silanes. 1999. The benefits of privatization: Evidence from Mexico. Quarterly Journal of Economics 114 (November): 1193-1242.

Larraín, Felipe, and Rodrigo Vergara. 2000. Un cuarto de siglo de reformas fiscals. In La transformación económica de Chile, ed. Felipe Larraín and Rodrigo Vergara, 71-109. Santiago: Centro de Estudios Públicos.

Levinsohn, James, and Amil Petrin. 1999. When industries become more productive, do firms? Investigating productivity dynamics. Working Paper 6893. National Bureau of Economic Research.

Lustig, Nora. 1998. Mexico: The remaking of an economy. 2nd ed. Washington, DC: Brookings Institution.

Pavcnik, Nina. 2000. Trade liberalization, exit, and productivity improvements: Evidence from Chilean plants. Working Paper 7852. National Bureau of Economic Research.

Sachs, Jeffrey. 1989. The debt overhang of developing countries. In Debt, stabilization and development: Essays in memory of Carlos Diaz-Alejandro, ed. Ronald Findlay et al., 80-102. Oxford: Blackwell.

Sanhueza, Gonzalo I. 2001. Chilean banking crisis of the 1980s: Solutions and estimation of the costs. Working Paper 104. Banco Central de Chile.

United Nations. 1986. National Accounts Statistics: Main Aggregates and Detailed Tables, 1984. New York: United Nations. 